\title{
PSYCHIATRY IN THE COURTROOM: RELYING ON THE AMERican Psychiatric Association's Manuals to Resolve Disputes About Personal Status
}

\author{
JANET DOLGIN ${ }^{*}$
}

\section{INTRODUCTION}

Successive editions of the American Psychiatric Association's Diagnostic and Statistical Manual (DSM) have provided a useful, if challenging, reference for courts in cases that require assessments of mental health. ${ }^{1}$ Most of those cases involve criminal defendants. ${ }^{2}$ This Article considers judicial reliance on DSM diagnostic categories in cases involving matters of personal status. ${ }^{3}$ It examines the potential benefits as well as the disadvantages of that reliance.

The Article explores two substantive domains. The first includes cases in which transgender people have sought the right to be identified legally in harmony with gender identity rather than the sex assigned to them at birth and to be treated fairly as members of the gender conforming with their identity rather than their sex at birth. The second domain includes cases implicating parental status.

Each set of cases involves momentous consequences for those involved. Transgender litigants often depend on a medical diagnosis in seeking a wide variety of legal rights (e.g., the right to coverage for medical care, ${ }^{4}$ the right to obtain employment, ${ }^{5}$ the right to obtain gender-conforming documentation such

* Jack and Freda Dicker Distinguished Professor of Health Care Law, Maurice A. Deane School of Law at Hofstra University; Professor of Science Education, Donald and Barbara Zucker School of Medicine at Hofstra/Northwell. I am indebted to Hofstra law school for the support that made completion of this Article possible, to Isaac Samuels, Reference Librarian, Hofstra law school, for his skill at identifying bibliographic references and his generous guidance with research; to Jean Krebs, joint JD-MPH degree student, Hofstra University, for her careful research assistance; and to Jennifer Calautti and Michelle Wallace, administrative assistants at Hofstra law school, for their capable work and generous help.

1. Ralph Slovenko, The DSM in Litigation and Legislation, 39 J. Am. ACAD. Psychiatry \& L. 6 (2011).

2. Id. at 6-8.

3. Courts have relied on psychiatric testimony and on the American Psychiatric Association's Diagnostic and Statistical Manuals in cases involving criminal responsibility, civil commitment, disability determinations, and termination of parental rights, among other matters. See, e.g., Slovenko, supra note 1. Psychologists join psychiatrists in relying on and interpreting DSM diagnostic categories.

4. See, e.g., Flack v. Wis. Dept. of Health Servs., 328 F. Supp. 3d 931 (W.D. Wis. 2018) (finding for plaintiff seeking preliminary injunction to prevent state Medicaid program from excluding "transsexual surgery" from medical coverage); see infra, Part III(B)(3).

5. See, e.g., Equal Emp't Opportunity Comm'n v. R.G. \& G.R. Funeral Homes, Inc., 884 F.3d 560 (2018) (allowing Equal Employment Opportunity Commission to move forward with Title VII claim against employer on "the theory that Stephen's failure to conform to sex stereotypes was 
as a birth certificate). ${ }^{6}$ The law's failure to recognize and protect the right of transgender populations to live in conformity with gender identity can pose onerous burdens on transmen and transwomen in almost every domain of everyday life. The most recent edition of the DSM (DSM-5) offers transgender people a mitigated diagnosis that provides a basis for seeking coverage for medical transition and that avoids serious stigmatization of the sort that accompanied reliance on earlier DSM editions. ${ }^{7}$ In contrast, in the second set of cases examined in this Article, a parent's having been diagnosed with a mental disorder is not likely to serve that parent in litigation threatening him or her with the termination of parental rights. ${ }^{8}$ The consequences can be draconian for children and their parents. ${ }^{9}$

For judges, asked to assess the implications of gender identity for transgender litigants or to discern the scope and implications of a parent's mental disorder in parental termination cases, DSM diagnostic categories provide a useful frame of reference. Judicial reliance on the DSM serves some litigants more than others. As a general matter, at least since the appearance of the fifth edition of the DSM in 2013, courts' reliance on DSM diagnostic categories has served transgender litigants seeking broader rights. The DSM may also serve parents seeking to retain parental rights but, at least as often, the manual provides judicial justification for terminating parental rights. In both types of cases, judicial reliance on DSM diagnostic categories can have profound consequences for litigants.

Part II of this Article summarizes the development of the DSM from the appearance of DSM-I in 1952 until the most recent edition, DSM-5, published in 2013. ${ }^{10}$ It considers use of DSM diagnostic categories in cases involving

the driving force behind the termination). In 2020, the U.S. Supreme Court concluded that Title VII protects employees fired on the basis of transgender status. Bostock v. Clayton County, Ga, 140 S. Ct. 1731, 590 U.S. (2020).

6. See, e.g., F.V. v. Barron, 286 F. Supp. 3d 1131 (2018) (issuing injunction to preclude state employees from refusing to recognize gender change applications from sex noted on birth certificate).

7. See infra, Part III.

8. See infra, Part IV.

9. Similar reliance on psychiatric testimony and similar references to provisions in successive editions of the American Psychiatric Association's Diagnostic and Statistical Manual of Mental Disorders could be offered in the context of other sorts of cases in which essential liberty rights are at stake. See William M. Brooks, The Tail Still Wags the Dog: The Pervasive and Inappropriate Influence by the Psychiatric Profession on the Civil Commitment Process, 86 N.D.L. REV. 259 (2010). Brooks questions the role of psychiatrists in civil commitment proceedings. He suggests that their "bias toward treatment," and their inability successfully to assess the risk of a person's dangerousness can preclude fairness for a person being assessed for civil commitment. Id. at 264 .

10. The first four DSM editions were designated with Roman numerals (DSM-I, DSM-II, DSM-III, and DSM-IV). The most recent edition was designated with an Arabic numeral (DSM-5). See infra, note 13 . 
diagnosis and assessment of parties' mental status. Further, it introduces and analyzes some of the benefits and the limitations of judicial reliance on DSM diagnostic categories. Parts III and IV respectively review judicial reliance on the DSM in cases involving transgender populations and in cases involving potential loss of parental rights. Judicial reliance on DSM diagnoses in cases about transgender rights increased significantly after appearance of DSM-5 in 2013. That reflects increased tolerance toward transgender people within society as well as significant changes in the American Psychiatric Association's (APA's) understanding of gender identity. Reliance on DSM diagnoses in cases involving parents at risk of losing their children goes back further in time. The Article focuses on two distinct types of termination cases - those involving parents diagnosed with substance abuse disorder (categorized as a mental disorder in the DSM) and a case in which an expert, relying on DSM diagnostic categories, diagnosed a surrogate mother, facing loss of parentage, with a mental disorder. Finally, Part V reviews the benefits and disadvantages of judicial reliance on DSM diagnostic categories in cases occasioned by both sorts of personal status disputes reviewed in the Article.

\section{THE DIAGNOSTIC AND STATISTICAL MANUALS AND THEIR USE IN COURTROOMS}

Lawmakers generally do not - and for the most part, should not - presume to understand the scope and implications of the terms "mental illness" or "mental disorder" beyond the understanding of the public generally. Legislators and judges look to psychiatrists for guidance. But there is more than one elephant in that room: psychiatrists, themselves, do not speak with a unified voice in assessing instances of presumptive mental illness or even in describing the symptoms and implications of mental illnesses. Furthermore, psychiatrists may be reluctant to apply the diagnostic categories with which they work for forensic purposes. ${ }^{11}$ That is troubling insofar as DSM diagnostic categories, as well as changes in the DSM over time, may "have an impact on the liberties of individuals by providing the justification for decisions related to coercive treatments, assertive outpatient treatment, preventative commitment, or the termination of parental rights," as well as other matters. ${ }^{12}$

The Diagnostic and Statistical Manuals of the APA - first published as DSMI in 1952 and most recently as DSM-5 in $2013^{13}$ - are primarily intended, as the

11. American Psychiatric Association, Diagnostic and Statistical Manual-IV-TR xxx (2000) [hereinafter DSM-IV-TR].

12. Dominic Sisti \& Rebecca Johnson, Revision and Representation: The Controversial Case of DSM-5, 29 PuBLIC AFF. Q. 76, 79 (2015) (noting that the "DSM is a manual that carries indirect coercive authority").

13. American Psychiatric Association, Diagnostic and Statistical Manual of Mental Disorders (DSM-5) (2013) [hereinafter DSM-5]. The APA published DSM-I in 1952; DSM-II in 1968; DSM-III in 1980; DSM-III-R in 1987; DSM-IV in 1994; DSM-IV-TR in 2000; and DSM-5 in 2013; See infra, Part II (reviewing history of the APA's publication of successive 
title suggests, to summarize a broad panoply of psychiatric diagnoses using a plethora of psychiatric diagnostic categories. ${ }^{14}$ The DSM editions have delineated diagnostic categories for use throughout the nation and in other nations. They have offered a road map for psychiatric and psychological research and have provided diagnostic categories for use by insurance companies and other healthcare payors.

By the end of the first decade of the present century, one edition or another of the DSM had been cited in more than 5,500 court decisions. ${ }^{15}$ Courts have looked to psychiatric diagnostic categories for a variety of purposes ${ }^{16}$ in cases involving, among other matters, issues about criminal responsibility, ${ }^{17}$ disability ${ }_{1}{ }^{18}$ insurance coverage, ${ }^{19}$ civil commitment to mental health facilities, ${ }^{20}$ transgender rights, ${ }^{21}$ and termination of parental rights. ${ }^{22}$ The DSM has aided- and sometimes confused - courts in each sort of case in their efforts to interpret statutory and judicial uses of phrases such as "mental illness" and "mental disorder" by offering psychiatrists' understandings of those and related, cognate phrases. Understanding the interplay between developments in psychiatry and the law's reliance on DSM diagnostic categories requires historical contextualization.

The history of the DSM's construction arguably goes back to the midnineteenth century, long before the appearance of the first Diagnostic and

DSM editions).

14. See generally Jeffrey A. Lieberman, Shrinks: The Untold Story of Psychiatry (2015).

15. Slovenko, supra note 1 (noting as well that during the same time period, the Manual was cited over 320 times in legislation).

16. Id. at 6 .

17. See, e.g., Com. v. Montanez, 769 N.E.2d 784, 796 (Mass. App. Ct. 2002) (reversing conviction for second degree murder and noting that a mental disorder's not being "codified as a specific diagnostic category in DSM-IV does not mean that it is not a recognized disorder").

18. See, e.g., Special Disability Trust Fund, Dept. of Labor \& Employment Security v. P.B. Newspaper/United Self Insured, 697 So.2d 1226, 1227 (Fla. Dist. Ct. App. 1997) (appellant "Trust Fund" appealed order concluding that claimant Lane's injury "merged" with "preexisting psychological disorder;" court noted that DSM-IV did not list "any psychological disorder . . . as a disease").

19. Fitts v. Unum Life Ins. Co. of Am., 520 F.3d 499 (2008) (questioning terms of disability insurance policy for employee diagnosed with bipolar disorder).

20. See, e.g., Dodd v. Hughes, 81 Nev. 43, 46 (Nev. 1965) (Dodd, seeking to be released from mental hospital, argued that "a person must exhibit one of the psychotic reactions as classified by the American Psychiatric Association before he may be considered mentally ill').

21. See, e.g., Doe v. Mass. Dep't Correction, 2018 U.S. Dist. LEXIS 99295 (D. Mass 2018) (considering prison housing of transwoman); Gonzalez v. Nevares, 305 F. Supp. 3d 327 (D.P.R. 2018) (transgender individuals and organizations sought right to correct birth certificates so that they would reflect gender identity); see infra Part III.

22. See, e.g., Matter of Commitment of Timothy Maurice B., 626 N.Y.S.2d 665 (N.Y. Fam. Ct. 1995). 
Statistical Manual of Mental Disorders (DSM-I) in 1952. ${ }^{23}$ The first DSM (DSMI) tracked the World Health Organization's International Classification of Diseases (ICD-6), focusing on diagnosis of psychiatric conditions. ${ }^{24}$ The second edition of the DSM (DSM-II), published in 1968, followed the model of the first, offering very few changes. ${ }^{25}$ Then DSM-III, first published in 1980, included significant innovations. ${ }^{26}$ Among them, this edition largely abandoned the psychoanalytic approach that had dominated American psychiatry until that time and that had informed the first two editions of the DSM. ${ }^{27}$ The members of the APA Task Force charged with revising DSM-II, relied on "symptoms-based criteria" for identifying psychiatric disorders. ${ }^{28}$ Historian Edward Shorter described the volume that resulted as "a redirection of the discipline towards a scientific course." ${ }^{29}$ DSM-IV (published in 1994) and its revision, DSM-IV-TR (published in 2000) relied on the framework presented in DSM-III. ${ }^{30}$

The fourth edition stated explicitly that the manual, while "provid[ing] a classification of mental disorders," did not "specif[y] precise boundaries for the concept of "mental disorder." "31 DSM-IV-TR continued to use the term mental disorder but explained that choice as a result of the absence of a satisfying alternative term. ${ }^{32}$ The text's Introduction explained the term and its meaning by referring to its preservation from DSM-III. It noted that "it is as useful as" any other option. ${ }^{33}$

None of the manuals was crafted with legal conundrums in mind. That was

23. Annemarie Goldstein Jutel, Putting a Name to It: Diagnosis in Contemporary Society 6 (2011) (noting that the "predecessor" to the DSM offered a "statistical classification" of patients and "was designed to improve communication about the types of patients cared for in [mental] hospitals.") The Association of Medical Superintendents of American Institutions for the Insane recognized psychiatry as a medical specialty in the mid- nineteenth century. Alina Suris, Ryan Holliday \& Carol S. North, The Evolution of the Classification of Psychiatric Disorders, https:/www.ncbi.nlm.nih.gov/pmc/articles/PMC4810039/ [https:/perma.cc/K555-PVBW]. The first organized effort to categorize mental disorders in the U.S. began through the work of the U.S. Census Bureau, interested in discerning the level of mental illness in the U.S. for the census taken in 1920. Id.

24. DSM History, AMERICAN PSYCHIATRIC ASSOCIATION, https://www.psychiatry.org/ psychiatrists/practice/dsm/history-of-the-dsm [https://perma.cc/97UV-U467] (last visited Mar. 23, 2020).

25. Id.

26. $I d$.

27. Jeffrey A. Lieberman, Shrinks: The Untold Story Of Psychiatry 134 (2015).

28. Id. at 135.

29. Edward Shorter, History of Psychiatry: From the Era of the Asylum to the Age of Prozac 302 (1997).

30. Lieberman, supra note 27, at 271.

31. Diagnostic And Statistical Manual-IV-TR, supra note 11.

32. Id. (noting that "unfortunately the term ["mental disorder"] persists in the title of DSM-IV because we have not found an appropriate substitute").

33. Id. at xxxi. 
explicit in both DSM-IV-TR (2000) and its replacement, DSM-5 (2013). Both editions assert openly - almost by way of a warning - that DSM diagnoses were not crafted for use in forensic settings. DSM-5, echoing DSM-IV-TR, ${ }^{34}$ refers to the "risk that diagnostic information will be misused or misunderstood" when invoked "in forensic settings." 35 Thus, lawmakers, looking for clarification about the implications of a mental illness ("mental disorder") ${ }^{36}$ and diagnoses of mental illnesses may be disappointed or confused when they turn to the DSM for guidance or may, unwittingly, rely on concepts devised for responding to very different situations than those at stake in most legal contexts.

Further, judicial and legislative reliance on DSM categories must be assessed in light of disagreements about DSM diagnostic categories among psychiatrists. The most recent edition, DSM-5, published in 2013, has been particularly controversial within the profession and among non-psychiatrists. ${ }^{37}$ Before compilation of DSM-5, its authors promised to ground psychiatry in biology. ${ }^{38}$ That did not happen, at least in part because the science needed to effect that ambition "was not on hand." ${ }^{39}$ Just before the edition's official publication, the Director of the National Institute of Mental Health (NIHM) expressed disappointment in the effort to revise the fourth edition of the DSM and proclaimed that NIHM would "be re-orienting its research away from DSM categories . . . to begin to develop a better system." ${ }^{40}$ He explained:

[W] cannot design a system based on biomarkers or cognitive performance because we lack the data . . . The diagnostic system has to be based on the emerging research data, not on the current symptombased categories. Imagine deciding that EKGs were not useful because many patients with chest pain did not have EKG changes. That is what we have been doing for decades when we reject a biomarker because it does not detect a DSM category. ${ }^{41}$

Yet, DSM-5 made significant changes to DSM-IV-TR (the 2000 revision of the

34. Id. at xxxii-xxxiii.

35. American Psychiatric Association, Diagnostic And Statistical Manual (DSM5) at 25 (2013).

36. The Diagnostic and Statistical Manuals use the term "mental disorder," rather than "mental illness," in their titles and refer throughout to "mental disorders." But courts and the public often use the term "mental illness" rather than "mental disorder."

37. Lieberman, supra note 27, at 274-76.

38. Anne Harrington, Mind Fixers:Psychiatry's Troubled SeArch for the Biology of Mental ILLnESS 268 (2019).

39. Id. at 269 .

40. Id. at 267 (quoting and citing Tom Insel, Transforming Diagnosis, NIMH Director's BlogPosts from April 29, 2013).

41. Thomas Insel, Transforming Diagnosis, NIMH Blog Posts (April 29, 2013), https://www.nimh.nih.gov/about/directors/thomas-insel/blog/2013/transforming-diagnosis.shtml [https://perma.cc/WT7L-J534]. 
fourth DSM edition). These included an expansion of diagnostic categories ${ }^{42}$ new explanations for those categories, including attention to "societal impact,"43 significant shifts in accounting for and diagnosing depressive disorders, ${ }^{44}$ and a focus on "degrees of severity" of a mental disorder. ${ }^{45}$ DSM-5 also abandoned the multiaxial system on which DSM-IV hinged. ${ }^{46}$ The public took an interest in the shape of DSM-5. National news media reported on some of the changes reflected in DSM-5 and the disagreements that those changes occasioned within psychiatry. ${ }^{47}$

Both Dr. Robert Spitzer, the psychiatrist who led the effort that produced DSM-III and Dr. Allen Francis, chair of the team that worked on revisions that led to DSM-IV, criticized the process that led to DSM-5 as well as some of the changes it contained. ${ }^{48}$

These criticisms and internal disagreements held consequences for society beyond the domain of psychiatric care. That becomes clear in the cases examined in this Article. Diagnosis with a mental illness can alter lives. It can occasion clinical attention and treatment, stigmatization and ostracism, relief from responsibility, even financial benefits or hardship as well as general relief and/or increased stress. One psychiatric diagnosis may facilitate a person's receiving

42. J.S. Blumenthal-Barby, Psychiatry's New Manual (DSM-5): Ethical and Conceptual Dimensions, 40 J. MED. ETHICs 531 (2014). The fifth edition included diagnoses not found in DSMIV and DSM-IV-TR, including "binge eating disorder, internet gaming disorder, caffeine use disorder, hoarding disorder, premenstrual dysphoric disorder." Id. at 531.

43. Id.

44. Jerome C. Wakefield, DSM-5: An Overview of Changes and Controversies, 41 CLIN. SoC. WORK J. 139, 140 (2013) (asserting that this set of alterations constituted "some of the most incendiary proposals and far-reaching changes" in DSM-5). Shifts in the chapter on depressive disorders included the elimination of the DSM-IV exclusion for depression occasioned by grief (the so-called "bereavement exclusion"). Id. at 148. Elimination of this exclusion created concern about pathologizing a set of responses that seemed common and perfectly normal - something "central to human experience." Id.

45. Blumenthal-Barby, supra note 42, at 531. Correlatively, DSM-5 provided for various diagnoses based on a lower number of symptoms than was the case with DSM-IV and DSM-IV-R; Eric G. Waldon, DSM-5: Changes and Controversies, 32 Music Therapy Perspectives 78, 79 (2014).

46. Wakefield, supra note 44 , at 140 (noting that the change was largely instituted to render psychiatry "more like general medicine and the need to coordinate with the ICD"). ICD is the World Health Organization's "International Classification Of Diseases."

47. Benedict Carey, Grief Could Join List of Disorders, N.Y. Times (Jan. 24, 2012) (noting "skirmish over the definition of depression" occasioned by "proposed change to the diagnosis [that] would characterize grieving as a disorder and greatly increase the number of people treated for it"). The article noted that many of the proposed changes for DSM-5 were "deeply contentious in the field." Id. Drafts of proposed alterations for DSM-5 were publicized online before the edition appeared. $I d$.

48. Id. 
social and public benefits and another may preclude that. ${ }^{49}$ Even more, diagnostic options may influence the "design of services." ${ }^{50}$ The sociologist Annemarie Goldstein Jutel asserted that "[t]he social impact of having a particular diagnosis is considerable." ${ }^{.51}$ She continued:

Beyond its organizational role and the access it provides to resources, diagnosis can stigmatize as well as legitimize, with psychiatry often guarding the boundaries between deviance and disease. Unexplained physical distress is often expressed as a psychiatric diagnosis. With few exceptions, only the medical profession has the power to diagnose disease; this medical custodianship of diagnosis reinforces medical authority. ${ }^{52}$

Furthermore, the Chair of the DSM-IV committee that was responsible for revisions that led to that edition of the DSM contended that the new diagnoses in DSM-5 threatened to "'radically and recklessly" expand psychiatric authority. ${ }^{53}$ Some have viewed the expansion of diagnostic categories to pose especially worrisome risks, especially insofar as many psychiatric diagnoses are made by primary care physicians rather than by psychiatrists. ${ }^{54}$ Equally concerning, that expansion may have been connected with financial conflicts of interest among panel members who developed the DSM-IV and DSM-5. Those conflicts have raised widespread concern. ${ }^{55}$ Some fear that these conflicts limited the usefulness of certain new diagnostic categories for patients ${ }^{56}$ and that the expansion of diagnostic categories is more likely to benefit the pharmaceutical industry than people in need of psychiatric help. ${ }^{57}$

49. Martyn D. Pickersgill, Debating DSM-5: Diagnosis and the Sociology of Critique, $40 \mathrm{~J}$. MeD. ETHICs 524 (2014).

50. Id.

51. Annemarie Goldstein Jutel, Putting a Name to It: Diagnosis in Contemporary SocIETY xiii (The Johns Hopkins Univ. Press, 2011).

52. Id.

53. Katie Moisse, DSM-5 Criticized for Financial Conflicts of Interest, ABC NEWS NETwORK (Mar. 13, 2012), https://abcnews.go.com/Health/MindMoodNews/dsm-fire-financial-conflicts/ story?id=15909673 [https://perma.cc/2LD9-AAW7] (quoting Dr. Allen Francis, who chaired the revisions committee for the DSM-IV).

54. Id.

55. Id. (reporting that many members of the task force and expert panels that developed DSM-5 received pay from the pharmaceutical industry as "spokespeople or scientific advisors for drug companies").

56. Lisa Cosgrove \& Sheldon Krimsky, A Comparison of DSM-IV and DSM-5 Panel Members' Financial Associations with Industry: A Pernicious Problem Persists, PLOS MED 9(3) (2012).

57. Lisa Cosgrove et al., Tripartite Conflicts of Interest and High Stakes Patent Extensions in the DSM-5., 83 PsychotherAPy \& Psychosomatics 106 (2014). Cosgrove et al. report that 27 percent of DSM-5 working group members had one or more financial conflicts of interest because of a connection to a drug manufacturer, and 61 percent of task force members had a 
All of these factors may limit the usefulness of DSM categories in legal settings. That concern is exacerbated by the APA's own disclaimer and warning that the Association's diagnostic manuals aim to assist in clinical diagnoses and not to serve lawmakers in establishing individuals' competence, responsibility or disability. ${ }^{58}$ The introduction to DSM-IV explains that position:

When the DSM-IV categories, criteria, and textual descriptions are employed for forensic purposes, there are significant risks that diagnostic information will be misused or misunderstood. These dangers arise because of the imperfect fit between the questions of ultimate concern to the law and the information contained in a clinical diagnosis. In most situations, the clinical diagnosis of a DSM-IV mental disorder is not sufficient to establish the existence for legal purposes of a "mental disorder," "mental disability," "mental disease," or "mental defect." In determining whether an individual meets a specified legal standard (e.g., for competence, criminal responsibility, or disability), additional information is usually required beyond that contained in the DSM-IV diagnosis. $^{59}$

Ralph Slovenko, a psychologist and lawyer who studied the use of DSM diagnostic categories in forensic settings, ${ }^{60}$ suggested that this caveat (repeated in DSM-5) ${ }^{61}$ may primarily serve as "a safeguard against liability." ${ }^{62}$ Yet, as if to mitigate its own warning about the use of DSM diagnostic categories in legal contexts, DSM-IV-TR immediately followed the warning by suggesting the Manual's usefulness in such settings:

When used appropriately, diagnoses and diagnostic information can assist decision makers in their determinations. For example, when the presence of a mental disorder is the predicate for a subsequent legal determination (e.g., involuntary civil commitment), the use of an established system of diagnosis enhances the value and reliability of the determination. By providing a compendium based on a review of the

financial conflict because of a connection with a drug manufacturer. Id. at 109 . With regard to the development of DSM-5, Lisa Cosgrove and co-authors found that, "[T]here may be a risk of industry influence on the DSM revision process. Additionally, our findings of FCOI of PIs running the clinical trials suggest that there also may be a risk of industry influence on the clinical decisionmaking process for identifying interventions to treat these new "disorders.'” Id. at 112.

58. In re Timothy Maurice B., 165 Misc. 2d 122, 128 (1995).

59. DSM-IV-TR, supra note 11, at xxxii-xxxiii. DSM-IV-TR is an undated version of DSMIV, not a new edition. The central change involved "updating the diagnostic codes to be compatible with ICD-9." Diagnostic and Statistical Manual of Mental Disorders: DSM-IV vs. DSM-IV-TR, A History OF THE DSM through CASE StUdiEs, http://dsmistory.umwblogs.org/dsm-iv/influentialpeople-and-studies/ [https://perma.cc/WM5U-U4TA].

60. See Slovenko, supra note 1.

61. DSM-5, supra note 13, at 25.

62. Slovenko, supra note 1 , at 6 . 
pertinent clinical and research literature, DSM-IV may facilitate the legal decision makers' understanding of the relevant characteristics of mental disorders ... [D]iagnostic information regarding longitudinal course may improve decision making when the legal issue concerns an individual's mental functioning at a past or future point in time. ${ }^{63}$

Thus, concerns about use of the DSM in legal settings notwithstanding, courts and legislatures have continued to rely on DSM diagnostic categorizations. The next two Parts of this Article consider that reliance first (in Part III), in cases involving the status and fair treatment of transgender people and second (in Part IV), in cases in which parents have faced the loss of parental rights. In each set of cases, legal decisions have implicated personal status, and in each set of cases, courts or litigants have looked to DSM diagnostic categories to draw legal conclusions about individuals' gender or about their right to continue parenting their children.

\section{TRANSGENDER IDENTITY AND THE DSM}

Whether or not transgender status is identified as a medical condition has important consequences for transgender populations. ${ }^{64}$ Identifying transgender people with a psychiatric disorder can result in or exacerbate stigmatization. ${ }^{65}$ However, transgender individuals seeking medical treatment to transition physically so that their bodies will be in harmony with their gender identities will not be covered by health insurance policies if the condition is not defined as medical. And more generally, it may help those seeking equal treatment for transgender people if they are able to categorize the condition as medical, rather than a matter of individual choice.

Within the last few years, courts have increasingly ${ }^{66}$ looked to DSM diagnoses in cases involving the right of transgender individuals to serve prison

63. DSM-IV-TR, supra note 11, at xxxiii; see also, Slovenko, supra note 1, at 6. DSM-5 reiterates the same message, DSM-5, supra note 13, at 25. However, DSM-5 proceeds to reiterate the risks of diagnostic categories being "misused or misunderstood" when "employed for forensic purposes." Id.

64. The gender identity of transgender people differs from their sex at birth. Between .2 to .5 percent of the population is transgender. Gary J. Gates, LGBT Identity: A Demographer's Perspective, 45 Loy. L.A. L. Rev. 693, 698 (2012) (citing Gary J. Gates, How Many People Are Lesbian, Gay, Bisexual, and Transgender? The Williams Institute 5 (2011), http:// williamsinstitute.law.ucla.edu/wp-content/uploads/Gates-How-Many-People-LGBT-Apr-2011.pdf [https://perma.cc/5LKT-583K]).

65. Recent concern has focused on the exclusion of transgender people from bathrooms, sports teams, and locker rooms. See Janet Dolgin, Transgender Women on College Athletic Teams - The Case of Lindsay Hecox, 383 N. Eng. J. MED. 2000 (2020); Janet Dolgin, Discriminating Gender: Legal, Medical, and Social Presumptions About Transgender and Intersex People, $47 \mathrm{Sw}$. L. REv. 61, 96-113 (2017).

66. A WestLaw search for "transgender /p (diagnostic AND DSM)" for cases decided before 2012 identified four cases; the same search for cases decided after 2011 identified 22 cases. 
terms in gender-conforming facilities, ${ }^{67}$ to be treated fairly at work, ${ }^{68}$ to have birth certificates modified so that they are consonant with gender identity, ${ }^{69}$ to gain access to coverage for medical care needed to transition, ${ }^{70}$ as well as other matters. Increasingly since the appearance of DSM-5 in 2013, litigants seeking equity for transgender people have invoked DSM diagnostic categories. That follows from the American Psychiatric Association's having significantly reshaped its discussion of transgender status between DSM-IV and DSM-5, with the interests of transgender people in mind. ${ }^{71}$

DSM-IV included a transgender diagnosis within a category of psychiatric disorders referred to as "Sexual and Gender Disorders." This diagnostic category included three sub- categories: "Sexual Dysfunctions, the Paraphilias, and the Gender Identity Disorders." 72

There must be evidence of a strong and persistent cross-gender identification, which is the desire to be, or the insistence that one is, of the other sex ... There must also be evidence of persistent discomfort about one's assigned sex or a sense of inappropriateness in the gender role of that sex. To make the diagnosis, there must be evidence of clinically significant distress or impairment in social, occupational or other important areas of functioning. ${ }^{73}$

DSM-5 renamed the diagnosis, referring to what had been labelled "gender identity disorder" as "gender dysphoria." 74 Gender dysphoria was not categorized with "Sexual and Gender Disorders" (as DSM-IV had categorized gender identity disorder) but received a section of its own in the new DSM. ${ }^{75}$ These changes diminished the stigmatization inherent in DSM-IV's label which asserted that being transgender entailed having a psychiatric "disorder." Yet, retaining the condition in DSM-5 - though under a new diagnostic label - provided for a medical diagnosis. That is of significance to members of the transgender

67. Doe v. Mass. Dep't of Corr., No. 17-12255-RGS, 2018 U.S. Dist. LEXIS 35022 (D. Mass. Mar. 5, 2018) (case initiated by transgender woman seeking transfer from men's prison to women's prison).

68. Glenn v. Brumby, 724 F. Supp. 2d 1284 (N.D. Ga. 2010).

69. Gonzalez v. Nevares, 305 F. Supp. 3d 327 (D.P.R. 2018).

70. Good v. Iowa Dep't Human Servs., 924 N.W.2d 853 (Iowa 2019); Flack v. Wis. Dep't of Health Servs., 395 F. Supp. 3d 1001 (W.D. Wis. 2019).

71. This re-shaping served the interests of those effected by the relevant DSM category. More specifically, it allowed transgender people to seek coverage for medical transition but not at the expense of the profound stigmatization that accompanied earlier DSM characterizations of transgender people. See infra notes and accompanying text.

72. DSM-IV-TR, supra note 11 , at 535.

73. DSM-IV-TR, supra note 11, at 576 (noting as well that the gender identity disorder will not be applied to someone who "has a concurrent physical intersex condition").

74. "Gender identity disorder" was defined quite differently from "gender dysphoria." However, the second replaced the first in DSM-5. See DSM-5, supra note 13, at 451-59.

75. DSM-5, supra note 13, at 451-59. 
population who seek reimbursement for medical expenses related to sex reassignment. ${ }^{76}$ DSM-5 offers separate diagnostic criteria for gender dysphoria in children and in adolescents and adults. ${ }^{77}$ A crucial component of the diagnosis for all age groups is that the individual feel distress. DSM-5 explains this requirement for the diagnosis of gender dysphoria: "The condition is associated with clinically significant distress or impairment in social, occupational, or other important areas of functioning." " 78 Thus, gender identity among transgender people is not a mental disorder. Unhappiness produced by that identity may be.

In short, a mental disorder ("gender dysphoria") cannot be diagnosed pursuant to DSM- 5 unless the individual feels "distress or impairment" with regard to gender identity. ${ }^{79}$ This change from DSM-IV effectively asserts that the psychiatric disorder is not the underlying condition. Rather, the disorder can be identified only through reference to a person's dysphoria. ${ }^{80}$

\section{A. Cases About Transgender Status Decided Before Publication of DSM-5}

Before the appearance of DSM-5 in 2013, not many court decisions involving transgender litigants seeking civil rights referred to the DSM ${ }^{81}$ In only two of those cases was the court's reference to the DSM of more than passing concern. This may reflect changes made to the DMS between DSM-IV and DSM-5. Even more, it likely reflects the increasing readiness of society to acknowledge unfairness in the treatment of transgender people and, accordingly, the increasing readiness of transgender people to seek legal redress when they face discrimination. ${ }^{82}$

This sub-section reviews two cases involving transgender rights that were

76. Wakefield, supra note 44 , at 146.

77. DSM-5, supra note 13, at 452-453. The Manual categorizes adolescents and adults together.

78. DSM-5, supra note 13, at Sec. 302.85(B), p. 453. The explanation with regard to children reads: "The condition is associated with clinically significant distress or impairment in social, school, or other important areas of functioning." Id. at Sec. 302.6(B), p. 452.

79. Some transgender people, as well as some other people, prefer to be referred to by the neutral pronouns "they, them, their," rather than by the singular pronouns, he, him, his or she, her, her. LGBT Resource Center, Gender Neutral Pronouns, UnIVERSITY OF S. CALIF., https://gbtrc. usc.edu/trans/transgender/pronouns/ [https://perma.cc/M4C3-V5XV] (last visited Apr. 16, 2020). Others prefer single pronouns such as sie, hir, and hir or zie, zir, and zir. Id.

80. This diagnostic revision may be a harbinger, suggesting that the category will be removed from the diagnostic categorizations of a future Manual. Wakefield, supra note 44, at 146.

81. A WestLaw search for "adv: transgender/p diagnostic AND DSM AND DATE (bef 2012)" identified only four cases, all decided between 2002 and 2010. WestLaw reported no such cases for 2012. DSM-5 appeared in 2013. DSM-5, supra note 13.

82. See, e.g., G. G. v. Gloucester Cnty. Sch. Bd., 822 F.3d 709 (4th Cir. 2016) (transgender boy sued for right to use boys' bathroom at school), judgment vacated, 137 S. Ct. 1239 (2017) (vacating and remanding due to DOE and DOJ's guidance document); Bd. of Educ. v. U.S. Dep't Educ., 208 F. Supp. 3d 850 (S.D. Ohio 2016). 
decided before 2013. These were the only cases decided by a court before 2013 that raised issues about transgender rights and made more than a passing reference to the DSM. The first was decided by a Massachusetts court in 2002. A transwoman sued her employer for discriminating against her after she began to transition. ${ }^{83}$ The employer, who referred to the plaintiff as a "cross-dresser" or "transvestite," told plaintiff to wear "traditionally female clothing" while at work ${ }^{84}$ and threatened her with " "disciplinary action and/or termination" if she failed to comply. ${ }^{85}$ The plaintiff, Allie Lie, continued to wear women's attire. She referred to herself as "transgendered" or "transsexual." The court noted that the difference in the parties' language was significant. ${ }^{86}$ Its explanation of that claim referred to and quoted DSM-IV:

The term "transsexual" . . specifically refers to those individuals who could be diagnosed as having a gender identity disorder (Diagnostic Code 302.85 [in DSM- IV] when referring to adolescents or adults) under the rubric provided by the psychiatric community:

Adults with Gender Identity Disorder are preoccupied with their wish to live as members of the other sex. This preoccupation may be manifested as an intense desire to adopt the social role of the other sex or to acquire the physical appearance of the other sex through hormonal or surgical manipulation. Adults with this disorder are uncomfortable being regarded by others as, or functioning in society as, a member of their designated sex. ${ }^{87}$

Writing for the court, Judge Giles concluded that Lie had "establish[ed] she is a transsexual, not simply a man who prefers traditionally female attire." ${ }^{18}$ Judge Giles allowed the case to go forward on three of the plaintiff's four counts. ${ }^{89}$

In Sundstrom v. Frank, ${ }^{90}$ plaintiffs, all transgender prison inmates or former

83. Lie v. Sky Publ'g Corp., No. 013117J, 2002 WL 31492397 (Mass. Super. 2002). First, the plaintiff filed a charge against the defendant with the Cambridge Human Rights Commission. The Commission found probable cause. $I d$. at 2 .

84. Id. at 1. Lie filed a charge with the Massachusetts Commission Against Discrimination but later withdrew that charge and brought suit in court. Id. at 3. The defendant fired plaintiff, with knowledge of her having filed a complaint. $I d$. at 8 .

85. Id. at 2 .

86. Id. at 1 .

87. Id. at 2 (quoting American PSychiatric Association, Diagnostic AND Statistical Manual of Mental Disorders-Fourth Edition (“DSM-IV”), at 533 (1994)).

88. Id. at 2 .

89. Id. at 9 (noting that court allowed the defendant's motion of summary judgement with regard to one count and denied it with regard to three other counts). No subsequent history has been reported.

90. Sundstrom v. Frank, 630 F. Supp. 2d 974 (E.D. Wis. 2007). The case, at this stage, involved various motions by both sides. The plaintiffs sought to exclude certain testimony, and the defendants sought certain evidentiary rulings. 
inmates, ${ }^{91}$ relied on DSM-IV's diagnostic categories despite those categories' stigmatization of transgender people. ${ }^{92}$ The plaintiffs brought a civil rights action $^{93}$ against prison officials, including prison physicians, claiming that the officials' enforcement of a state law that "abruptly terminat[ed] and depriv[ed] [the prisoners] of medical treatment for their serious health condition, Gender Identity Disorder (GID)," was unconstitutional..$^{94}$ A year earlier, the court had granted a motion by the plaintiffs for a preliminary injunction, enjoining the prison from terminating hormone therapy for the plaintiffs. ${ }^{95}$

The plaintiffs sought to exclude testimony from a psychologist, Daniel Claiborn, who had opined that "GID is not a legitimate health condition, and that the American Psychiatric Association's Diagnostic and Statistical Manual of Mental Disorders (DSM) is not authoritative ..." ${ }^{, 96}$ Dr. Claiborn had stated:

I do not believe the plaintiffs' transgender situations represent a mental disorder, a medical condition, or a diagnosable disease requiring treatment. Thus, I believe, to a reasonable degree of psychological certainty, that their transgender issues do not result in serious medical needs. The experts in the field do not view GID as a pathological entity, and my experience as a therapist, GID evaluator, and student of the literature all reinforce that the transgender situation is about choices, not medical necessity. In fact, each transgender individual decides which options to pursue and how far and how fast to go with regard to these life-changing options--based on age, physical characteristics, income, employment, personality, pain tolerance, and desired lifestyle, among other considerations. ${ }^{97}$

In response, plaintiffs contended that Dr. Claiborn had himself acknowledged that he was " "not an expert on the DSM and its possible political motivations' nor is he aware that the revisions to the DSM are based on extensive scientific literature reviews, scientific data analysis, and scientific research." ${ }^{98}$ Nevertheless, Judge Clevert, writing for the federal district court, denied the plaintiffs' motion to exclude Dr. Clairborn's report, referring, among other matters, to "Dr. Claiborn's years of experience [between thirty and fifty] treating transgender patients." The

91. Kari Sundstrom and Lindsey Blackwell, two of the original plaintiffs, were later dismissed from the suit after having been released from prison. Id.

92. See supra notes 81 and 82 and accompanying text.

93. Sundstrom, 630 F. Supp. $2 d$ at 977 . The case was brought for declaratory and injunctive relief under 42 U.S.C. $\S 1983$.

94. Id. The relevant state law was Wis. STAT. $§ 302.386(5 \mathrm{~m})$. The Wisconsin Inmate Sex Change Prevention Act ("Act 105") precluded the authorization of any state funds or resources "to provide or to facilitate the provision of hormonal therapy or sexual reassignment surgery." Fields v. Smith, 653 F.3d 550, 533 (7th Cir. 2011).

95. Sundstrom, 630 F. Supp. $2 \mathrm{~d}$ at 977.

96. Id. at 977-78.

97. Sundstrom, 630 F. Supp. 2 d at 977.

98. Id. at 980 (internal citations omitted). 
court deemed that experience "significant" exclude Dr. Claiborn's testimony. ${ }^{100}$

The case went to trial in 2010. ${ }^{101}$ Despite his approval of Dr. Clairborn's testimony, Judge Clevert found that the Wisconsin law that resulted in withdrawal of treatment for transgender inmates in state prison violated the federal Constitution's Eighth and Fourteenth Amendments. ${ }^{102}$ The court therefore granted the plaintiffs' request for a permanent injunction, precluding the state from withholding medical care needed to respond to the "serious medical condition of Gender Identity Disorder (GID)."'103

The Seventh Circuit affirmed. The circuit court referred to the three plaintiffs' having been diagnosed with Gender Identity Disorder ("GID"), in conformity with the DSM-IV-TR diagnostic category:

GID is classified as a psychiatric disorder in the DSM-IV-TR, the current edition of the American Psychiatric Association's Diagnostic and Statistical Manual of Mental Disorders. Individuals with GID identify strongly with a gender that does not match their physical sex characteristics. The condition is association with severe psychological distress. ${ }^{104}$

The circuit court, agreeing with the district court, stressed that the Eighth Amendment's ban on cruel and unusual punishment precluded a state's denying treatment "for the serious medical needs of prisoners." 105 Thus, despite the stigmatization inherent in DSM-IV's treatment of gender identity disorder, the manual proved useful to plaintiffs seeking medical treatment needed to transition physically.

\section{B. Cases Decided After Publication of DSM-5}

Publication of DSM-5, with its revised understanding of gender identity, facilitated the cause of transgender litigants in a number of contexts. The cases considered in this Section all involve transgender litigants who relied on "gender dysphoria" diagnoses, pursuant to DSM-5. The first case involved a successful claim of employment discrimination. The next two cases considered, respectively, in subsection (2) and (3) of this Section involved transgender prisoners seeking fair treatment in prison. The fourth case, considered in subsection (4), involved transgender litigants who sought health care coverage from Wisconsin's Medicaid

99. Id. at $977-78$.

100. Id. at 983 . The court proceeded to reject defendants' motion to exclude portions of a report by a psychologist who testified for the plaintiffs. $I d$. at 987 . The court granted plaintiffs' motion to exclude medical opinions that had been offered by a corrections expert. Id.

101. Fields v. Smith, 712 F. Supp. 2 d 830 (E.D. Wis. 2010).

102. Id.

103. Id. at 869-70.

104. Id. at 556 .

105. Id. (7th Cir. 2011) (citing and quoting Estelle v. Gamble, 429 U.S. 97, 103-04 (1976). 
program for transgender surgery.

1. Blatt v. Cabella. ${ }^{106}$ - Until recently, transgender litigants seeking civil rights were precluded from claiming discrimination pursuant to both the Americans with Disabilities Act (ADA) ${ }^{107}$ and Section 504 of the Rehabilitation Act of 1973. ${ }^{108}$ A window opened for them, however, in 2017. In Blatt v. Cabella, a federal district court in Pennsylvania re-interpreted ADA and Section 504 exclusions that had blocked transgender people from claiming a disability that might make them eligible for ADA or Section 504 protection. ${ }^{109}$

The ADA defines disability as "a physical or mental impairment that substantially limits one or more major life activities." 110 For transgender litigants, however, showing that transgender status was a disability pursuant to the ADA was not possible $\mathrm{e}^{111}$ because the ADA contains an exclusion from the definition of disability that includes "transvestism, transsexualism, pedophilia, exhibitionism, voyeurism, gender identity disorders not resulting from physical impairments, or other sexual behavior disorders." ${ }^{12}$ This exclusion is combined with others, "compulsive gambling, kleptomania, or pyromania," 113 presenting a disturbing concatenation of excluded disorders. Similarly, in 1988, a congressional amendment to the Fair Housing Act excluded transgender status from protection under the Fair Housing Act and Section 504 of the Rehabilitation Act. ${ }^{114}$

These exclusions effectively precluded ADA and Section 504 protection for people facing discrimination on the basis of transgender status. Yet, in Blatt, ${ }^{115}$ the court concluded that 'transsexualism' was not, per se, a disability pursuant to

106. Blatt v. Cabela’s Retail, InC., 2017 U.S. Dist. LEXIS 75665 (E.D. Pa. 2017).

107. 42 U.S.C. $\S 12101$ (2020).

108. 29 U.S.C. $\$ 701(2020)$.

109. Blatt v. Cabela's Retail, Inc., 2017 U.S. Dist. LEXIS 75665 (E.D. Pa. 2017).

110. Doe v. Mass. Dep’t of Corr., 2018 U.S. Dist. LEXIS 99925, 13 (D. Mass. 2018) (quoting and citing 42 U.S.C. $\S 12101(\mathrm{~b})(1))$. The court noted that because the "definition of disability in both [acts] is virtually identical[,] . . . "courts routinely apply the same legal analysis in interpreting claims under both statutes." Id.

111. In Doe, the federal district court accepted the transgender litigant's claim that the treatment she received limited her reproductive capacity (a "major life activity"). Doe v. Mass. Dep't of Corr., 2018 U.S. Dist. LEXIS 99925, *14-*15 (D. Mass. 2018). See also Bragdon v. Abbott, 524 U.S. 624, 639 (1998) (acknowledging that reproduction is a "major life activity for the purposes of the ADA").

112. 42 U.S.C. $\S 12211(b)(1)(2020)$.

113. 42 U.S.C. §Sec. 12211(b)(2) (2020).

114. Fair Housing Amendments Act of 1988, Pub. L. No. 100-430, § 6(b)(3), 102 Stat. 1619, 1622 (1988) (codified as a note to 42 U.S.C. 3602); see Kevin M. Barry \& Jennifer L. Levi, Contemporary Issues in Disability Rights Law: The Future of Disability Rights Protections for Transgender People, 35 Touro L. REv. 25, 38 (2019) (considering Section 504 exclusion of transgender status).

115. 2017 U.S. Dist. LEXIS 75665 (E.D. Pa. 2017). 
the ADA but that the ADA exclusion did not cover cases of gender dysphoria. ${ }^{116}$ The case had been brought by a transgender woman against her employer. The plaintiff, Kate Lynn Blatt, had been diagnosed with gender dysphoria, delineated in DSM-5. ${ }^{117}$ She argued that the employer's discrimination against her violated Title VII of the Civil Rights Act of $1964^{118}$ and the ADA. The court denied the employer's motion to dismiss, concluding that the ADA exclusion did not include people diagnosed with gender dysphoria and explained that this conclusion precluded the need to consider the constitutionality of that exclusion: the statute could be interpreted to exclude many transgender people but not those diagnosed with gender dysphoria. Here, the court explained that the employer's interpretation of gender identity disorders depended on the language in an outdated edition of the DSM:

Cabela's suggested interpretation aligns with the ... definition in the revised third edition of the American Psychiatric Association's Diagnostic and Statistical Manual of Mental Disorders (the current edition at the time of the drafting of the ADA), where the term gender identity disorders is defined as broadly encompassing any disorder essentially marked by "an incongruence between assigned sex . . . and gender identity." 119

Thus, the court placed significant weight on changes made to the DSM between DSM-III (relied on by the employer in Blatt v. Cabela) and DSM-5 (current when the case was decided). The district court denied Cabela's request to dismiss Blatt's ADA claims, thus allowing Blatt to litigate those claims. ${ }^{120}$ Before that could happen, the parties settled the case. ${ }^{121}$

The decision in Blatt encouraged transgender litigants to challenge discrimination against them as violative of the ADA and Section 504. In 2019, two law professors identified fifteen recently decided or pending discrimination cases commenced by transgender litigants who based ADA or Section 504 claims on gender dysphoria diagnoses. ${ }^{122}$ In several of these cases, courts referenced the

116. Id.

117. Id. at $* 4$.

118. See 42 U.S.C. $§ 2000$ e (2019). As this article was being prepared for publication, the Supreme Court decided Bostock v. Clayton County, Ga. 140 S. Ct. 1731, 590 U.S. _ (2020) (recognizing discrimination against transgender people as sexual discrimination under Title VII).

119. Blatt v. Cabela's Retail, Inc., 2017 U.S. Dist. LEXIS 75665 at *6 n.1 (E.D. Pa. 2017). (citing DSM-III at 71).

120. Id. at $* 11$.

121. Barry \& Levi, supra note 114, at 54; Jim Vasil, Schuylkill Woman Settles Transgender Suit Against Cabela's, WFMZ-TV 69 NEWs (Sep. 27, 2017), wfmz.com/news/area/berks/schuylkillwoman-settles-transgender-suit-against-cabela-s/article_d9048c8d-32b2- 54b4-ad7080af69545908.html) [https://perma.cc/N85G-L2AL].

122. Barry \& Levi, supra note 114 , at 52 . Cases in which transgender people challenged discriminatory practices include three broad types of claims - those involving discrimination (e.g., in employment settings), those brought by prisoners, and those relating to "insurance and identity 
DMS-5.

2. Doe v. Massachusetts Department of Correction.-Doe v. Massachusetts Department of Correction involved a transgender woman in prison for a nonviolent drug offense. ${ }^{123}$ The Department had housed Jane Doe in a men's prison where, her complaint alleged, she suffered a "litany of humiliations and trauma." ${ }^{24}$ Male guards, strip-searching Doe, "groped her breasts." ${ }^{125}$ She was forced to take off all of her clothing "in plain view of other prisoners," all male; some of them "made audible sexually suggestive comments about [Doe's] body." 26 Male prisoners "gawked at her" when she showered and "harass[ed]" her in the bathroom. ${ }^{127}$ Prison guards commented that Doe was "still a man" and referred to her and other transgender women as "chicks with dicks' and "wannabe women." ${ }^{28}$ Further, Doe alleged that some male prisoners "attempted to physically force themselves on her." ${ }^{\prime 29}$ Doe alleged discrimination under the Americans with Disabilities Act (ADA) ${ }^{130}$ and Section 504 of the Rehabilitation Act of 1973 (Section 504) ${ }^{131}$ as well as the Due Process Clauses of the Fourteenth Amendment of the U.S. Constitution. ${ }^{132}$

In response to the Department of Correction's reliance on the provision in the ADA that excluded "transvestism, ... . [and] gender identity disorder[s]" as "outside the scope of the statute's definition of "disability," 133 Doe referred to DSM-5's treatment of "[g]ender [d]ysphoria" as support for the claim that her condition involved more than "gender identification." 134 On that basis, Doe distinguished her condition - gender dysphoria - from the meaning given to "gender identity disorders" that had been excluded from ADA coverage. ${ }^{135}$ Further, Doe contended that her condition was not encompassed by the ADA exclusion because her gender dysphoria did result from "physical impairments." 136 Doe then argued that if the ADA exclusion did refer to "all diagnoses of GD [gender dysphoria], it violates the Fourteenth Amendment because the legislative history of the exclusion demonstrates that it was driven by

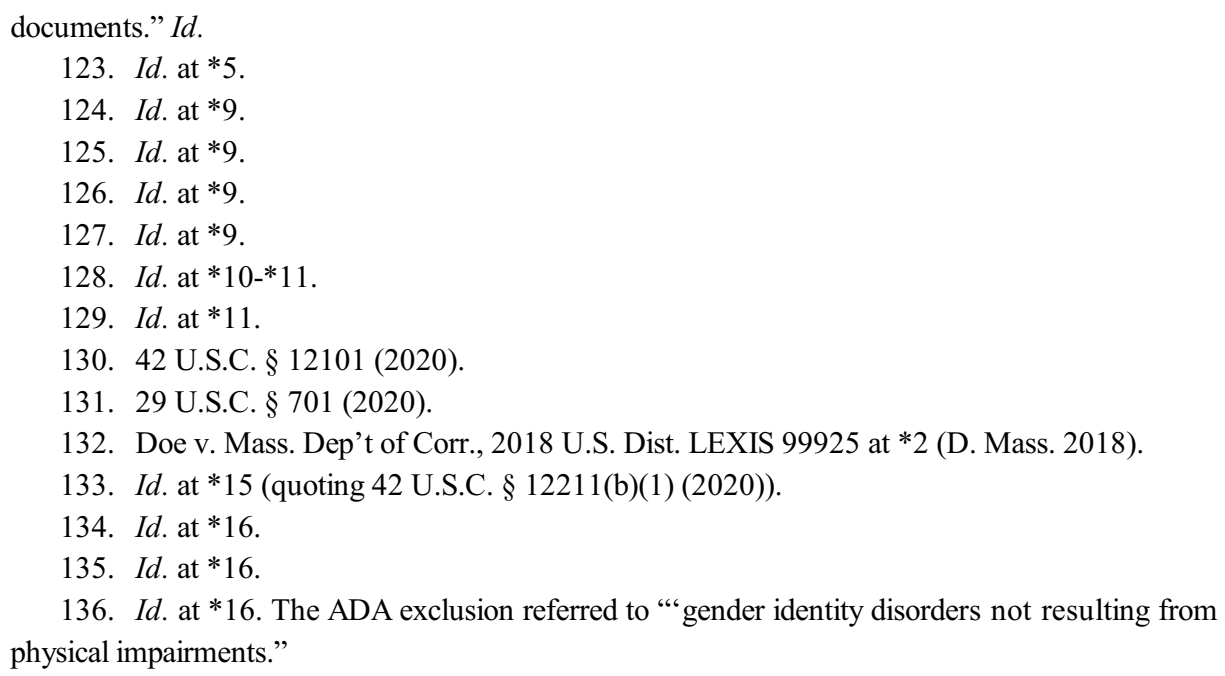


animus toward transgender persons."

The district court - which reviewed DSM-5's understanding of gender dysphoria at some length - agreed. ${ }^{138}$ The court concluded that the ADA and section 504 exclusions did not include gender dysphoria. ${ }^{139}$ The court referred to the definition of "gender identity disorders" in DSM-IV and compared that with the provision in DSM-5 that "the diagnosis of GD . . requires attendant disabling physical symptoms, in addition to manifestations of clinically significant emotional distress." ${ }^{140}$ Even more, the district court explained that were the ADA exclusion to be read to "bar Doe's claim," the exclusion would seem to violate the Fourteenth Amendment's Equal Protection Clause. ${ }^{141}$

Deciding that Jane Doe was likely to "prevail on her ADA and Equal Protection claims," the district court denied the Department's Motion to Dismiss. ${ }^{142}$ A few months after the court rendered this decision, Jane Doe was transferred to a woman's prison facility. In the same year, both Connecticut and Massachusetts promulgated laws that mandated that result for transwomen in prison. ${ }^{143}$

3. Edmo v. Idaho Department of Correction. ${ }^{144}$-Adree Edmo, a transwoman, brought suit against the Idaho Department of Corrections. Imprisoned in 2012, Edmo was diagnosed with gender dysphoria two months later by a Department of Corrections psychiatrist. ${ }^{145}$ Edmo was treated with hormone therapy, ${ }^{146}$ but the treatment did not relieve her gender dysphoria. Twice during the next several years she attempted self-castration. ${ }^{147}$ Her continued suffering led her to seek gender confirming surgery. When the correctional department refused to provide her with that remedy for her condition, Edmo brought suit. ${ }^{148}$

After careful review of expert testimony and professional texts about gender dysphoria, the Idaho federal district court concluded that the Department's refusal to provide gender conforming surgery for Edmo violated the Eighth

137. Id. at *16-17.

138. Id. at *6-7; *17-18.

139. Id. at $* 17-18$.

140. $I d$. at $* 18$.

141. Id. at *19. The court relied on "the doctrine of constitutional avoidance" which requires a court, seeing the possibility of a statute's invalidation pursuant to the U.S. Constitution to seek a statutory construction that would avoid the constitutional challenge. Id. at 18-19.

142. Id. at *32-33. The court directed the parties to discuss relief that could be offered to Jane Doe without court intervention. Id.

143. Barry \& Levi, supra note 114, at 61 (citing MASS. GEN. LAWs ch. 127, § 32A (2018) and Conn. Gen. Stat. § 18-81ii (2018)).

144. Edmo v. Idaho Dep't of Corr., 358 F. Supp. 3d 1103, 1103 (D. Idaho 2018); aff'd sub nom. Edmo v. Corizon, 935 F.3d 757 (9th Cir. 2019).

145. 358 F. Supp. 3d at 1109

146. Id.

147. Id.

148. Id. at 1103 . 
Amendment. ${ }^{149}$ That Amendment includes a right enjoyed by prisoners to satisfactory medical treatment while in prison. ${ }^{150}$ That right pertains, however, only if the prisoner's medical needs are "serious." ${ }^{51}$ The court found that Edmo's condition was adequately serious and explained that a prisoner would have a constitutional right to care if the prison failed

to treat a prisoner's condition [that] could result in further significant injury or the unnecessary and wanton infliction of pain [;] . . [ [t]he existence of an injury that a reasonable doctor or patient would find important and worthy of comment or treatment; the presence of a medical condition that significantly affects an individual's daily activities; or the existence of chronic and substantial pain. ... ${ }^{152}$

In its "findings of fact" related to the seriousness and character of gender dysphoria, the district court relied on DSM-5, summarizing the manual's presentation of gender dysphoria. ${ }^{153}$ The court further summarized guidelines for treatment of gender dysphoria in the World Professional Association of Transgender Health (WPATH). ${ }^{154}$ These texts, along with extensive expert testimony, supported the court's conclusion that Edmo suffered from gender dysphoria and that "gender dysphoria is a serious medical condition recognized by the DSM-5." 155 In light of these conclusions and the "Standards of Care" recommended by WPATH, the district court ordered defendants to provide gender conforming surgery to Edmo. ${ }^{156}$

The Ninth Circuit similarly relied on the discussion of gender dysphoria in DSM-5 and on treatment options presented in WPATH. ${ }^{157}$ The circuit court tracked DSM-5's delineation of the features of gender dysphoria, noting that DSM-5 required that an individual with gender dysphoria experience " clinically significant distress." 158 The State did not deny that Edmo had gender dysphoria, but it contended that the hormonal treatments that Edmo had received constituted "adequate and medically acceptable care." 159 The circuit court, echoing the

149. Id. at 1123 (quoting and citing Estelle v. Gamble, 429 U.S. 97 (1976)).

150. 58 F. Supp. $3 \mathrm{~d}$ at 1123.

151. Id.

152. Id. (citing and quoting McGuckin v. Smith, 974 F. 2d 1050, 1059-60 (9th Cir. 1992) (brackets and ellipses in original)).

153. Id. at 1110-11.

154. Id. at 1111 .

155. Id. at 1124 .

156. Id. at 1129. The Ninth Circuit affirmed the district court's injunction in Edmo's favor but vacated it with regard to certain individual defendants and a private company that had entered into a contract to provide health care to prisoners.

157. Edmo v. Corizon, Inc., 935 F.3d 757, 768-71 (9th Cir. 2019).

158. Id. at 769 (quoting and citing DSM-5 at 452). The court further relied on WPATH's Standards of Care's "“guidelines for treatment of individuals with gender dysphoria"” Id. (quoting Edmo, 358 F. Supp. 3d at 1111).

159. Id. at 786 . 
district court, disagreed:

The district court permissibly credited the opinions of Edmo's experts that GCS [gender confirmation surgery] is medically necessary to treat Edmo's gender dysphoria and that the State's failure to provide that treatment is medically unacceptable. Edmo's experts are well-qualified to render such opinions .... On the other side of the coin, the district court permissibly discredited the contrary opinions of the State's treating physician and medical experts. Those individuals lacked expertise and incredibly applied (or did not apply, in the case of the State's treating physician) the WPATH Standards of Care. ... The credited testimony establishes that GCS is medically necessary. ${ }^{160}$

Thus, the DSM-5 categorization of "gender dysphoria" as a mental disorder served Edmo as she argued that for her, surgery was medically necessary. An arguably similar diagnosis for other transgender litigants could, however, prove detrimental. For transgender prisoners who do not suffer from dysphoria, gender confirming surgery - even if desired-will likely not be deemed medically necessary. ${ }^{161}$

At about the same time, the Trump administration declared that transgender individuals diagnosed with gender dysphoria are " unfit" "to serve in the military. That declaration was justified by reference to the "serious medical need" of transgender people. ${ }^{162}$ This challenged the ideological and political aims that undergirded construction of DSM-5's "gender dysphoria" diagnosis. ${ }^{163}$

4. Flack v. Wisconsin Department of Health Services. ${ }^{164}$ - Cody Flack, a

160. Id. at 787. In November 2019, the district court considered and denied the defendants' expedited motion to stay but deferred establishing a deadline for aspects of Edmo's treatment. Edmo v. Idaho Dep't of Corr., No. 1:17-CV-00151-BLW, 2019 WL 5865620, at*1 (D. Idaho Nov. 8, 2019).

161. See William J. Rold, Federal Judge in Idaho Grants Preliminary Injunction for Confirmation Surgery for Transgender Inmate, 2019 LGBT L. NoTES 7 (2019).

162. Id.

163. The decision to rename gender identity disorder as gender dysphoria aimed, in part at destigmatization. That is a laudable goal, but the social goal and the new label may seem incongruous in the context of identifying a medical diagnosis. Wakefield, supra note 44, at 146 . Further, the author commented that:

[W] hen homosexuality was changed to ego-dystonic homosexuality, that portended the elimination of homosexuality completely form the Manual because logically the fact that one feels dysphoric about something that in itself is not disordered does not constitute a mental disorder unless it reaches major depression levels of severity. The same two-step process of depathologization may be occurring to gender identity disorder. Id.

164. Flack v. Wis. Dep't of Health Servs. 328 F. Supp. 3d 931 (W.D. Wis. 2018). See also Flack v. Wis. Dept Health Servs., 331 F.R.D. 261 (W.D. Wis. 2019) (related case seeking to name additional plaintiffs and asking the district court to certify a class; the court granted each of 
transman, and Sara Makenzie, a transwoman, sued the Wisconsin Department of Health Services, challenging the exclusion of transgender surgery from the state's Medicaid program. ${ }^{165}$ Both plaintiffs had been diagnosed with gender dysphoria. The court quoted DSM-5's definition of the condition and noted that, "if left untreated," gender dysphoria "can cause adverse symptoms." 166

Tracking the DSM-5's consideration of gender dysphoria, the court reported: Untreated, gender dysphoria can result in psychological distress: "preoccupation with cross-gender wishes often interferes with daily activities." [citing DSM-5] Impairment - such as the development of substance abuse, anxiety and depression-is also a possible "consequence of gender dysphoria." [citing DSM-5] Finally, gender dysphoria "is associated with high levels of stigmatization, discrimination, and victimization, leading to negative self-concept, increased rates of mental disorder comorbidity, school dropout, and economic marginalization, including unemployment, with attendant social and mental health risks. ..." [citing DSM-5 $]^{167}$

In the same vein, the court, again quoting DSM-5, reported that people "with gender dysphoria 'are at increased risk for suicidal ideation, suicide attempts, and suicides." "168 In short, DSM-5's categorization of gender dysphoria as a mental disorder was essential to the court's conclusion that the transgender plaintiffs in the case would "suffer irreparable harm" without injunctive relief. ${ }^{169}$ In consequence, the court enjoined the state from enforcing the Medicaid exclusion of transgender surgery against either of the transgender plaintiffs in the case. ${ }^{170}$ Without DSM-5's discussion of gender dysphoria, the Flack plaintiffs might well have fared less successfully in this litigation.

\section{TERMINATION OF PARENTAL RIGHTS AND THE DSM}

This Part summarizes the law's understanding of parentage and the situations in which parents may be at risk for losing custody of, or more onerously, parental rights to, their children. It then turns to the implications of a parent's being diagnosed with a mental disorder in termination cases. It considers those

plaintiffs' motions); Flack v. Wis. Dep't Health Servs., No. 18-CV-309-WMC, 2019 WL 2151702 , at $* 1$ (W.D. Wis. May 17, 2019) (denying defendants' motion to stay proceedings); Flack v. Wis. Dep't Health Servs., 395 F. Supp. 3d 1001 (W.D. Wis. 2019) (granting plaintiffs summary judgement and holding that Medicaid provision violated Affordable Care Act, Medicaid, and Equal Protection Clause).

165. Flack, 328 F. Supp. 3d 931, 934-35 (W.D. Wis. 2019) Plaintiffs also sought Medicaid coverage for drugs related to the surgery for which they were seeking coverage. Id.

166. Id. at 935 .

167. Id.

168. Id. at 936 .

169. Id. at 942 .

170. Id. at 955. 
implications with a set of California cases in which judges invoked the DSM in responding to claims of parental substance abuse. Finally, this Part turns to a dispute between a surrogate mother and intending parents in which psychiatric experts disagreed about the relevance of DSM diagnostic categories to an assessment of the surrogate's mental health.

\section{A. Deprivation and Uncertainty}

Parents have wide scope to decide how to raise their children. The state rarely interferes with a parent's right to make basic decisions for his or her child unless the parent's choices endanger the child. ${ }^{171}$ But when a child is found to be "abused, neglected or abandoned," 172 the state may deprive the parent or parents of the child's custody, at least temporarily. ${ }^{173}$

The termination of parental rights ${ }^{174}$ can involve a major life deprivation for parents - and for children, as well, even if the termination is necessary to safeguard the children's basic safety and welfare. Thus, the U.S. Supreme Court has concluded that statutory grounds for termination must be proven by clear and convincing evidence, a stricter standard than the preponderance of the evidence standard generally relied on in civil litigation. ${ }^{175}$ Grounds vary among the states. This Part focuses broadly on cases in which a parent's inability to provide for a child is the presumptive result of that parent's "mental disability, physical disability, substance abuse, incarceration or institutionalization."176

More specifically, the following sections of this Part consider cases in which courts predicated the termination of parental rights or considered terminating parental rights on the basis of a finding of a parental mental disorder. ${ }^{177}$ Section

171. 46 AM. JuR. Proof of Facts 3d 231, § 2 (originally published in 1998) [hereinafter Proof of Facts].

172. Id.

173. If the problem that created the need for a child's removal cannot be fixed, the state may commerce proceedings to terminate parental rights. $I d$.

174. Charisa Smith defines the termination of parental rights as "the process whereby courts force biological parents to sever their legal ties with their children in favor of upholding the "child's best interests' by imbuing other, allegedly more well-suited individuals with those parental rights." Charisa Smith, The Conundrum of Family Reunification: A Theoretical, Legal, and Practical Approach to Reunification Services for Parents with Mental Disabilities, 26 STAN. L. \& POL'Y REV. 307, 309 (2015) [hereinafter Smith, The Conundrum of Family Reunification].

175. Santosky v. Kramer, 455 U.S. 745 (1982).

176. Proof of Facts, supra note 171, at $\S 3$. "Mental disability" refers to mental illness or intellectual disability. $I d$. at $\S 5-6$.

177. The DSM uses the term "mental disorder," not "mental illness." DSM-5 defines "mental disorder" as follows:

A mental disorder is a syndrome characterized by clinically significant disturbance in an individual's cognition, emotion regulation, or behavior that reflects a dysfunction in the psychological, biological, or developmental processes underlying mental functioning. Mental disorders are usually associated with significant distress or 
$\mathrm{B}$ and $\mathrm{C}$ of this Part focus, in particular, on termination cases involving claims of parental substance abuse (defined as a mental disorder in DSM-5). ${ }^{178}$ In assessing that, courts routinely need guidance, especially insofar as many state statutes refer to "mental illness" but do not provide a definition of the term. ${ }^{179}$ Further, Section $\mathrm{D}$ of this Part considers a court case involving surrogate motherhood and examines a dispute among experts about the implications of a DSM diagnosis for the surrogate mother.

\section{B. Parents Diagnosed with Mental Disorders in Termination of Parental Rights Cases}

For parents facing termination of parental rights and diagnosed with mental disorders, a court's understanding of a psychiatric diagnosis and its relevance or not to the parents' capacity to care for their children can have far-reaching consequences. Even the fact that a parent has been diagnosed with a mental disorder, without more information, may bias judges handling a termination case to favor a termination order rather than to support continuing efforts to effect family reunification.

That sort of bias is not unique to judges or to termination cases. As a general matter, unrecognized or unacknowledged biases about mental illness can have far-reaching consequences for society since millions of adults in the U.S. "experience mental illness" each year. ${ }^{180}$ The NIH has estimated that almost 12

disability in social, occupational, or other important activities. An expectable or culturally approved response to a common stressor or loss, such as the death of a loved one, is not a mental disorder. Socially deviant behavior (e.g., political, religious, or sexual) and conflicts that are primarily between the individual and society are not mental disorders unless the deviance or conflict results from a dysfunction in the individual, as described above.

DSM-5, supra note 13, at 20.

178. See, e.g., DSM-5, supra note 13, "Substance-Related and Addictive Disorders," at p. 481 et seq. (2013).

179. Some states do offer definitions. In New York, for instance, mental illness is defined, in the context of termination of parental rights cases as:

[A]n affliction with a mental disease or mental condition which is manifested by a disorder or disturbance in behavior, feeling, thinking or judgment to such an extent that if such child were placed in or returned to the custody of the parent, the child would be in danger of becoming a neglected child as defined in the family court act.

NY Soc. Serv. § 384-b (2019). Substance abuse (referred to in DSM-5 as a "substance use disorder") is included in the Diagnostic and Statistical Manual as a psychiatric disorder. See, e.g., DSM-5, supra note 13, "Substance-Related and Addictive Disorders," at p. 481 et seq. (2013).

180. Mental Health by the Numbers, NAMI, https:/www.nami.org/learn-more/mental-healthby-the-numbers [https://perma.cc/Y9BQ-K5SH] (last visited Sept. 4, 2019); Transforming the Understanding and Treatment of Mental Illnesses, Prevalence of Any Mental Illness, NIH, https://www.nimh.nih.gov/health/statistics/mental-illness.shtml\#part_154785 [https://perma.cc/ TX4L-7Y73] (reporting 46.6 million adults in U.S. with a mental illness in 2017; that was 
million adults experienced "serious mental illness" in 2017. ${ }^{181}$ Even the more, bias against those diagnosed with mental illnesses can have unfortunate consequences. Overzealous efforts to protect children from parents diagnosed with mental illnesses can undermine the possibility of successful family preservation and reunification. ${ }^{182}$

1. Parental Rehabilitation.-Termination proceedings are rarely simple. Their success depends on a court's ability to understand and assess a child's needs and interests and parental rights and capacities. Further, in cases in which parents have been diagnosed with mental illness, good results for those involved also depend on the ability of courts to comprehend psychiatric testimony and DSM diagnostic categories, while interpreting that evidence in light of legal processes and family law more than in light of clinical psychiatric practice.

Judges responding overzealously to diagnoses of parental mental illness may not focus adequately on the positive potential of rehabilitative services. ${ }^{183}$ Serious mental illness can interfere with a parent's ability to care for his or her child, but it is not necessarily determinative of a poor outcome. ${ }^{184}$ Adequate treatment and social services are crucial as are reunification services, though admittedly not all are successful:

There are numerous ways that parents with mental disabilities can treat and manage their illnesses, improve their parenting skills, function successfully in society, and create safe and loving homes in which to regain and raise their children. Yet the care with which reunification services are statutorily and financially prioritized, publicly and privately administered, and inter-disciplinarily designed is highly determinant of any family's fate. ${ }^{185}$

2. Best Interests of Children, Psychiatric Expertise, and the DSM.Traditionally, court orders resulting in the termination of parental rights have depended, both as a matter of statutory law and judicial practice, on a standard aimed at assessing the "best interests" of the child or children involved. In significant part, those assessments are subjective. And for judges, they can be challenging.

The best-interest standard is venerable but also aspirational. In practice, it often provides a murky guide for judges determining a child's custodial

equivalent to 18.9 percent of the population 18 or older in the U.S.) (last visited Sept. 4, 2019) [https://perma.cc/S39Q-F6NB].

181. Transforming the Understanding and Treatment of Mental Illnesses, Prevalence of Any Mental Illness, NIH, https://www.nimh.nih.gov/health/statistics/mental-illness.shtml\#part_154785 (last visited Sept. 4, 2019) [https://perma.cc/S39Q-F6NB].

182. See infra and accompanying text (noting that a significant majority of adults with mental illness diagnoses have lost custody in termination cases).

183. Smith, The Conundrum of Family Reunification, infra note 176, at 310.

184. Id. at 315-17.

185. Id. at 310 . 
arrangements or legal parentage. ${ }^{186}$ Its "vagueness and indeterminacy . . . give[] judges broad discretion to consider almost any factor thought to be relevant ...."187 Statutory guidelines may delineate factors relevant to a child's welfare, but such guidelines do not generally inform the process of determining a child's interests adequately. ${ }^{188}$ The indeterminacy of the best interest standard reinforces the need for judges to rely on expert testimony.

In cases in which a parent has been diagnosed with a mental illness, including substance abuse disorder, wise judicial assessments depend on judges' understanding the implications of such diagnoses and the potential for rehabilitative efforts to provide a basis for family reunification. In this light, it is incumbent on the judicial system to provide judges handling custody and termination cases with information and guidelines about the implications of various diagnoses of mental illness. Appropriate responses to such diagnoses depend on judges' understanding the likely scope of a diagnosis and its implications for the likelihood that a parent provided with competent rehabilitation services will be able successfully to sustain the parent-child relationship. Testimony from psychologists and psychiatrists as well as familiarity with DSM diagnostic categories can offer useful guideposts to judges. ${ }^{189}$

186. Robert H. Mnookin, Child-Custody Adjudication: Judicial Functions in the Face of Indeterminacy, 39 L. \& CONTEMP. PROBS. 226 (1975).

187. Elizabeth S. Scott \& Robert E. Emery, Gender Politics and Child Custody: The Puzzling Persistence of the Best-Interests Standard, 77 L. \& CONTEMP. ProBs. 69 (2014). This limitation may explain the standard's survival over time. Even as the perseverance of the best-interest standard suggests that the standard offers a firm anchor to courts making decisions about a child's custody and/or parentage, the standard's flexibility has provided for shifting understandings over time of a child's best interest. That flexibility has facilitated the standard's survival. It has facilitated decisions grounded on a judge's individual insights, fueled by shifting socio-cultural preferences. See Janet L. Dolgin, Why Has the Best Interest Standard Survived?: The Historic and Social Context, 15 Children's Legal Rights J. (1996) (excerpted in DAVID RAy PAPKe ET AL., LAW AND POPUlar Culture (2d ed., 2007)).

188. The limitations of statutory guidelines in cases involving children's best interests may encourage judges to look to the testimony of experts for assessing a child's best interests, a process likely to include assessments of a child's psychological status and needs and of the psychological status of the child's parents.

189. Judges must be alert to the nuances of particular mental health diagnoses. Judges should, for instance, consider the possibility that expert testimony asserting that a parent facing termination of parental rights is mentally ill may create a false sense that science supports terminating parental rights, and such testimony may buttress courts' ill-formed conclusions about a child's safety and welfare. Susan Kerr, The Application of the Americans with Disabilities Act to the Termination of the Parental Rights of Individuals with Mental Disabilities, 16 J. Contemp. Health L. \& PoL'y 387, 388 (2000) (noting that people diagnosed "with mental disabilities consistently have their parental rights terminated and routinely lose their appeals."). Kerr includes within the label "mentally disabled" conditions "such as mental retardation, manic depression and schizophrenia." Id. at 404 . 
To some extent, in practice, constitutional law precludes courts from relying on broad presumptions (including presumptions about mental illness) to justify terminal of a parent's rights. ${ }^{190}$ It may be "more convenient to presume than to prove" various notions relevant to the retention of parental rights. ${ }^{191}$ But in cases threatening a parent with the termination of his or her parental rights, convenience must be sacrificed to Due Process. ${ }^{192}$ Thus, psychiatric diagnoses in cases involving the potential termination of parental rights are rarely determinative, without more. ${ }^{193}$

Further, the Constitution precludes states from identifying parents as unfit in the absence of "fair procedures." 194 Noting that "medical and psychiatric testimony" in termination cases does not generally offer certainty, the Court in Stanley v. Illinois concluded that a state cannot deprive a parent of his or her parental rights without "clear and convincing evidence" of that parent's unfitness. ${ }^{195}$ The next Section of this Article examines a series of cases in which the mental health of parents facing termination proceedings has played a significant role in directing judicial conclusions about the best interests of the child or children involved.

\section{Parents' Mental Health Status: Substance Use Disorder}

This section focuses on a set of parental termination cases decided in California during the first two decades of the twenty-first century. In these cases, courts relied on DSM diagnostic categories in order to discern the implications of parental substance abuse (categorized among DSM mental disorders). DSM diagnostic criteria for identifying substance abuse are more straightforward than diagnostic criteria delineated with regard to diagnosis of most mental disorders. ${ }^{196}$ More specifically, substance abuse, as described through reference to DSM criteria, can be assessed fairly easily by judges in light of the facts of specific cases. However, the process is not always straightforward. Judges may shape their conclusions about parental substance abuse through reference to the DSM

190. Stanley v. Illinois, 405 U.S. 645, 652-53 (1972) (precluding reliance on father's not having married children's mother to deprive him of paternal rights). In cases challenging a parent's parental rights, presumptions should not replace individual analysis:

Procedure by presumption is always cheaper and easier than individualized determination. But when, as here, the procedure forecloses the determinative issues of competence and care, when it explicitly disdains present realities in deference to past formalities, it needlessly risks running roughshod over the important interests of both parent and child. It therefore cannot stand.

Id. at 656-57 (footnote omitted).

191. Id. at 658 .

192. Id.

193. Id. at 642-57.

194. Santosky v. Kramer, 455 U.S. 745, 754 (1982).

195. Id. at 769-70.

196. See, e.g., DSM-5, supra note 13, at 481-589. 
or they may support or justify pre-formed conclusions through such references. It may be impossible in particular cases to distinguish one of these processes from the other.

According to DSM-5 "the diagnosis of a substance use disorder is based on a pathological pattern of behaviors related to use of the substance." 197 Diagnosis depends on several sets of criteria. ${ }^{198}$ The first relates to "impaired control." In the most "severe" cases this may mean that "virtually all of the individual's daily activities revolve around the substance." 199 The second group of criteria involves "social impairment." 200 This may involve "a failure to fulfill major role obligations at work, school, or home." ${ }^{201}$ The third group includes "risky use of the substance" which "may take the form of recurrent substance use in situations in which it is physically hazardous." 202 The final group of criteria delineated in DSM-5's discussion of substance use disorder are those categorized as "pharmacological."."203

The cases considered in this Section involve possible dependency jurisdiction for a child or children whose parents were alleged to have a substance use disorder. ${ }^{204}$ These cases suggest an evolving judicial reliance on DSM categorizations and, then, a partial retreat from such reliance. The Section reviews cases that illustrate both responses.

1. Jennifer A. v. Superior Court. ${ }^{205}$ - In 1987 the California legislature amended state law so that the child of a parent unable to care for his or her child as a result of substance abuse became eligible for dependency jurisdiction. ${ }^{206}$ The legislature did not define "substance abuse." Further, the legislative history did not help in the effort to discern the term's definition for purposes of the

197. DSM-5, supra note 13 , at 483 .

198. Id.

199. Id.

200. Id.

201. Id.

202. DSM-5, supra note 13, at 483. Risky use may also involve a person's continuing "substance use despite knowledge of having a persistent or recurrent physical or psychological problem that is likely to have been caused or exacerbated by the substance." In this situation, the person with a substance use disorder will fail "to abstain from using the substance despite the difficulty it is causing."

203. DSM-5, supra note 13 , at 484 . The pharmacological criteria include "tolerance" for the drug and the "withdrawal syndrome" which "occurs when blood or tissue concentrations of a substance decline in an individual who had maintained prolonged heavy use of the substance."

204. "Substance Use Disorder" is the phrase used in DSM-5, see "Substance Use Disorders," DSM-5, supra note 13, at 483. DSM-5 does not use the term "addiction" in reference to diagnoses; see also Mace Beckson \& \& Douglas Tucker, Commentary: Craving Diagnostic Validity in DSM-5 Substance Use Disorders, 42 J. AM. ACAD. Psychiatry L. 453, 456 (2014).

205. Jennifer A. v. Superior Court, 117 Cal. App. 4th 1322, 1326 (Cal. Ct. App. 2004).

206. CAL. Welf. \& InST. CODE $\S 300$ (Deering, current through Chapter 1 of the 2020 Regular Session). 
application of the relevant provision of state law. ${ }^{207}$

In Jennifer A. v. Superior Court, a state appellate court relied on the DSM for a definition for "substance abuse," as used in state statutory law. ${ }^{208}$ This provided one model for future courts asked to assess claims of parental substance abuse. Jennifer A's two sons, ages seven and three, were removed from her custody in 2002 after she went to work, leaving the two boys alone in a hotel room. Jennifer petitioned for relief from a juvenile court order that set a hearing date to consider termination of Jennifer's parental rights. ${ }^{209}$ That order was grounded on Jennifer's having missed a number of required drug tests and having tested positive for marijuana twice.

The order perplexed the appellate court insofar as Jennifer, despite her use of marijuana, seemed not to have a substance abuse problem, and her assigned social worker described Jennifer generally to exhibit good parenting skills. ${ }^{210}$ The court acknowledged that Jennifer had missed a number of drug tests. That and two positive tests for marijuana led to some concern. ${ }^{211}$ Yet, the court concluded that the children's health and welfare would not be jeopardized were they to be returned to their mother's custody. ${ }^{212}$ In reaching that conclusion, the court relied on the description of substance abuse in DSM-IV:

No evidence was presented to establish Mother displayed clinical substance abuse, that is, "[a] maladaptive pattern of substance use leading to clinically significant impairment of distress . . . occurring within a 12-month period." (Am. Psychiatric Assn. Diagnostic \& Statistical Manual of Mental Disorders (4th ed. 2000) p. 199.) No medical professional diagnosed Mother as having a substance abuse problem[.] $]^{213}$

Had Jennifer's substance use been shown to harmonize with DSM-IV's characterization of "clinical substance abuse," she might well not have regained custody of her boys. In the absence of evidence that DSM-IV's description of a substance use disorder applied to Jennifer, the appellate court directed the lower court to return Jennifer's boys to her. ${ }^{214}$

2. In re Drake $\mathrm{M}^{215}$ - In In re Drake M., a California appellate court, following the model in Jennifer A., looked to the DSM-IV for an appropriate

207. In re Drake M., 211 Cal. App. 4th 754, 765 (Cal. Ct. App. 2012).

208. Jennifer A., 117 Cal. App. 4th at 1322.

209. Id. at 1326.

210. Id. at 1327.

211. Id. at 1344 .

212. Id. at 1346.

213. Jennifer A., $117 \mathrm{Cal}$. App. 4th at 1346 (citing DSM-IV, supra note 11).

214. Id. at 1347. Return of Jennifer's children was made conditional on the absence at the hearing of new evidence suggesting that Jennifer was unlikely to provide her young sons with adequate parenting. $I d$.

215. In re Drake M., 211 Cal. App. 4th at 754. 
definition of parental substance abuse. ${ }^{216}$ The case involved review of a trial court decision that found Drake M., aged fourteen months, at risk because of his father's use of medical marijuana. ${ }^{217}$ The case was the first in California that questioned a child's custody on the basis of a parent's use of medical marijuana after the state legalized marijuana for medical use. ${ }^{218}$

Paul M., Drake's father, explained that his use of marijuana was medicinal, aimed at treating arthritic pain, presumably the result of his work as a cement mason. ${ }^{219}$ That work demanded that he spend several hours each day on his knees. ${ }^{220}$ Despite a report that noted the father's employment, the child's over-all health, and adequate support, the DCFS filed a petition, alleging that Paul M.'s use of "legal marijuana" interfered with his capacity adequately to protect Drake. ${ }^{221}$ The trial court permitted Paul M. to retain custody of the child but it required Paul to "submit to random drug testing and to attend parenting courses and drug counseling sessions." 222 The father appealed.

The appellate court concluded that the trial court had confused the implications of "substance use" and "substance abuse."223 The trial court acknowledged that the use of marijuana by Paul M. was medicinal and, therefore, "legal." 24 Yet, the court focused on the governing law which provided for dependency jurisdiction in light of " "the inability of the parent or guardian to

216. Id. at 766 .

217. Id. at 757; see also id. at 762 (noting dependency findings with regard to Drake M.'s mother were not challenged and would, the court stated, "continue to support dependency jurisdiction").

218. Marka B. Fleming \& Gwendolyn McFadden-Wade, The Unthinkable Choice, 25 B.U. PuB. INT. L.J. 299, 313 (2016); see In re Drake M., 211 Cal. App. 4th at 758, n.5. When still a baby, Drake was referred to the Department of Children and Family Services (DCFS) At that time, the Department found no evidence of abuse and noted that the child " appeared to be reaching developmental milestones.' Id. Drake M. was nine-months old when his case was first referred to the Department of Children and Family Services (DCFS). The appellate court decision does not identify the referring party. The juvenile court hearings are not available. The referring party expressed concern about the child's safety because of the parents' use of marijuana and the mother's history of drug abuse. The referring party apparently noted as well that the mother had "failed to reunify" with an older child whose case had been brought to the DCFS. Id. DCFS investigated the allegations. See generally id.

219. Id. at $757-58,760$.

220. Id. at 760 .

221. Id. at 758 .

222. Id. at 762. The trial court allowed Drake's mother to remain in the home on condition that she submitted to weekly drug tests and that those tests showed that she was not using drugs. Additionally, the court conditioned the mother's remaining in the home with Drake on her attending prescribed counseling programs and taking medication that had been prescribed for her. In short, "[f]amily reunification services were ordered for mother. Family maintenance services were ordered for father." $I d$.

223. In re Drake M., 211 Cal. App. 4th at 764.

224. Id. at 763 . 
provide regular care for the child due to the parent's substance abuse." ${ }^{225}$ That provision demanded evidence that the parent abused drugs in order to sustain dependency of the child. The requirement led the court to consider the statutory meaning of the phrase "substance abuse." In attempting to discern that, the appellate court followed the model crafted in Jennifer A. v. Superior Court. ${ }^{226}$ As in Jennifer A., the Drake court relied on DSM-IV-TR, the 2000 revised edition of DSM-IV. ${ }^{227}$

The appellate court in Drake $M$. concluded that a finding of parental substance abuse for the purpose of assuming dependency jurisdiction must depend either on the diagnosis of substance abuse by a medical professional or on a showing that the parent ${ }^{228}$ was a substance abuser through reference to the definition of "substance abuse" in DSM-IV-TR. ${ }^{229}$ Thus, the court defined the statutory term "substance abuse" in tune with the definition in the most recent edition of the DSM at the time of the decision. This approach, following that of Jennifer A., placed significant weight on DSM diagnostic categories in interpreting state law which provided that a child "may be "adjudge[d] . . . a dependent child of the court" 230 if a child's parent or guardian was unable "to provide regular care for the child due to the parent's or guardian's mental illness, developmental disability, or substance abuse." ${ }^{231}$

The court concluded that both DCFS and the trial court had "confused the meanings of the terms 'substance use' and 'substance abuse.""232 Tracking relevant provisions in DSM-IV-TR, the court explained that the components of

225. Id. at 757 n.2.

226. Jennifer A., 117 Cal. App. 4th at 1322.

227. DSM-5 appeared in 2013, a year after the decision in Drake M. In re Drake M., 211 Cal. App. 4th at 765. DSM-5 appeared in 2013, a year after the decision in Drake M. Drafts of its text had been made available earlier. The court relied on DSM-IV-TR (rev. ed. 2000).

228. Id. at 766. This conclusion included guardians as well as parents.

229. Id. The court quoted the "full" DSM definition of "substance abuse," adding to the part of the definition quoted in Jennifer A. See supra note 217 and accompanying text. See infra, note 237 and accompanying text.

230. CAL. Welf. \& INST. $\S 300$.

231. CAL. WelF. \& INST. § 300. Yet, pursuant to the statute, a parent's drug use that harmonized with that the relevant DSM diagnostic category (or that was diagnosed by a medical professional as a substance use disorder) was not sufficient for asserting dependency jurisdiction. In addition to a finding of a parental substance abuse (or other presumptively disordered states), the court had to find that the parent was unable to provide adequate care for his or her child.

232. 211 Cal. App. 4 at 764 . Further, the court explained, a finding of dependency jurisdiction based on

'the inability of the parent or guardian to provide regular care for the child due to the parent's ... substance abuse' must necessarily include a finding that the parent at issue is a substance abuser. We have previously stated that without more, the mere usage of drugs by a parent is not a sufficient basis on which dependency jurisdiction can be found.

Id. at 764 . 
the definition of substance abuse involved:

[a] maladaptive pattern of substance use leading to clinically significant impairment or distress, as manifested by one (or more) of the following, occurring within a 12-month period: [9] (1) recurrent substance use resulting in a failure to fulfill major role obligations at work, school, or home (e.g., repeated absences or poor work performance related to substance use; substance-related absences, suspensions, or expulsions from school; neglect of children or household)[; 9] (2) recurrent substance use in situations in which it is physically hazardous (e.g., driving an automobile or operating a machine when impaired by substance use)[; 9] (3) recurrent substance-related legal problems (e.g., arrests for substance-related disorderly conduct)[; and 9] (4) continued substance use despite having persistent or recurrent social or interpersonal problems caused or exacerbated by the effects of the substance (e.g., arguments with spouse about consequences of intoxication, physical fights). ${ }^{233}$

Considering each element delineated in the DSM-IV-TR, the court noted that Paul had fulfilled his obligations at work, had received a physician's recommendation for use of marijuana, and had had no legal problems related to substance abuse. There was no evidence "despite DCFS's allegations," that Paul had operated a vehicle while affected by marijuana or that he suffered from "recurrent social or interpersonal problems caused or exacerbated by marijuana." 234 In short, the court concluded that pursuant to the DSM-IV-TR definition of substance abuse, the DCFS had not provided evidence sufficient to show that Paul had a substance abuse problem. ${ }^{235}$ Moreover, the court concluded that Drake did not face a "risk of harm" from his father's use of marijuana. ${ }^{236}$

In both Jennifer $A .^{237}$ and Drake $M .^{238}$ California appellate courts looked to the DSM for a definition of substance abuse. In each case, the relevant court found that the parent at risk of losing parental rights did not fit the DSM criteria for substance use disorder. Thus, in each case the lower court ruling against the

233. In re Drake M., 211 Cal. App. 4th 754, 766 (Cal. Ct. App. 2012) (quoting and citing DSM-IV-TR, at p. 199).

234. Id. at 767-68.

235. Id. at 767-68.

236. Id. at 769 . The court concluded that

The trial court abused its discretion in ordering father to take parenting courses because such an order is not reasonably designed to eliminate mother's behavior, which led to the trial court's finding that Drake is a person described by section 300 .

Id. at 770-71.

237. See supra Part IV.C.1.

238. Jennifer $A$. and Drake $M$. were decided by different divisions of the California appellate court system. Jennifer A., 12 Cal. Rptr. 3d 572 (Cal. Ct. App. 2004) was decided by the Court of Appeal, Fourth District, Division Three, and Drake M., 149 Cal. Rptr. 3d 875 (Cal. Ct. App. 2012), was decided by the Court of Appeal, Second District, Division. 
parent was overturned.

3. In re Christopher R. ${ }^{239}$ - California courts began to assess and re-assess the significance that Jennifer $A$. and Drake $M$. paid to the DSM in subsequent termination cases involving parental substance use or abuse. ${ }^{240}$ In Christopher R., decided in 2014, a California appellate court, while bowing to the DSM, moved away from reliance on the APA's manuals. ${ }^{241}$ Questions facing the court in Christopher R. resembled those at stake in Jennifer A. and Drake M. Crystal R. (Christopher's mother) had four children. She and Frank G., the presumed father of Crystal's youngest child, an infant, appealed from a juvenile court order that declared the children dependents of the court. The order was based on Crystal's history of substance abuse and her continuing use of cocaine as well as Frank's history of substance abuse and current use of marijuana. ${ }^{242}$ Crystal contended that she had not used cocaine for seven years. However, both she and her youngest child, Brianna, tested positive for cocaine at the child's birth. ${ }^{243}$

The California appellate court that reviewed the case concluded that evidence of Crystal's drug abuse along with her "unstable lifestyle and cavalier attitude toward childcare" supported the lower court's finding that "Crystal's substance abuse endangered all four children's health and safety." 244 The court noted the absence of a legislative definition of substance abuse in the relevant statute. That statute identified "a parent's inability to provide regular care for his or her child due to substance abuse" as a "basis for dependency jurisdiction" 245 and expressly "recognize[d] the Drake $M$. formulation as a generally useful and workable definition of substance abuse" for purposes of understanding the law's reference to the condition. ${ }^{246}$ But the Christopher R. court limited its reliance on the DSM. The court explained:

239. In re Christopher R., 171 Cal. Rptr. 3d 14, modified, 2014 Cal. App. LEXIS 440 (Cal. Ct. App. 2014). Subsection 300(b) provides that a child who comes with the following description may be adjudged a dependent of the court. Subsection 300(b)(1) provides:

The child has suffered, or there is a substantial risk that the child will suffer, serious physical harm or illness, as a result of the failure or inability of his or her parent or guardian to adequately supervise of protect the child, or the willful or negligent failure of the child's parent or guardian to adequately supervise or protect the child from the conduct of the custodian with whom the child has been left, or by the willful or negligent failure of the parent or guardian to provide the child with adequate food, clothing, shelter, or medical treatment, or by the inability of the parent or guardian to provide regular care for the child due to the parent's or guardian's mental illness, developmental disability, or substance abuse.

Cal. Welf. \& Inst. Code $§ 300(b)(1)$.

240. See infra Part III.B.4.

241. In re Christopher R., 171 Cal. Rptr. 3d 14 (Cal. Ct. App. 2014).

242. Id. at 16 .

243. Id. Brianna was born in 2013. Id. at 17.

244. Id. at 20 .

245. Id.

246. Id. 
Not only are we not bound by Division Three's adoption of the DSM-IVTR's definition of "substance abuse" but also that definition has been replaced in the more recent Diagnostic and Statistical Manual of Mental Disorders, Fifth Edition (DSM-5), published in May 2013 after the decision in Drake $M$. by a more broadly defined classification of "substance use disorders," which combines substance abuse and dependence. $^{247}$

Although the Christopher $R$. court did not rely definitively on the broader classification of "substance use" in DSM-5 (published in 2013), the court noted the delineation of "11 relevant criteria" for identifying substance use disorders in DSM-5. ${ }^{248}$ These criteria included, cravings and urges to use the substance; spending a lot of time getting, using, or recovering from use of the substance; giving up important social, occupational or recreational activities because of substance use; and not managing to do what one should at work, home or school because of substance use. The manual provided that the presence of two or three of the 11 specified criteria indicated a mild substance use disorder; four or five indicated a moderate substance use disorder; and six or more a severe substance use disorder. ${ }^{249}$ While expressly limiting Drake M. 's formulation which relied on

247. Id., n.6.

248. Id

249. Id., n.6 (citing Highlights of Changes from DSM-IV-TR to DSM-5, AM. PSYCHIATRIC Ass'N (Apr. 14, 2014), http://www.dsm5.org/Documents/changes $\% 20$ from $\% 20 \mathrm{dsm}-\mathrm{iv}-\mathrm{tr} \% 20$ to\% 20dsm-5.pdf [https://perma.cc/8P4W-NXAL]). The criteria outlined for several substance abuse disorders are quite similar, each to the others. The DSM-5 diagnostic criteria for cannabis use disorder follow here:

A. A problematic pattern of cannabis use leading to clinically significant impairment or distress, as manifested by at least two of the following, occurring within a 12month period:

1. Cannabis is often taken in larger amounts or over a longer period than was intended.

2. There is a persistent desire or unsuccessful effort to cut down or control cannabis use.

3. A great deal of time is spent in activities necessary to obtain cannabis, use cannabis, or recover from its effects.

4. Craving, or a strong desire to urge to use cannabis.

5. Recurrent cannabis use resulting in a failure to fulfill major role obligations at work, school, or home.

6. Continued cannabis use despite having persistent or recurrent social or interpersonal problems caused or exacerbated by the effects of cannabis.

7. Important social, occupational, or recreational activities are given up or reduced because of cannabis use.

8. Recurrent cannabis use in situations in which it is physically hazardous.

9. Cannabis use is continued despite knowledge of having a persistent or recurrent physical or psychological problem that is likely to have been caused 
the DSM for a definition of substance abuse, the Christopher $R$. court hedged its bets by simultaneously explaining that Crystal's drug use would, if assessed against DSM guidelines, constitute substance abuse. ${ }^{250}$

Here, we believe Crystal's repeated use of cocaine and her ingestion of that drug while pregnant constitutes recurrent substance use that resulted in her failure to fulfill a major role obligation within the meaning of DSM-IV-TR. But even if Crystal's conduct fell outside one of the DSMIV-TR categories, we have no doubt her use of cocaine while in the final stage of her pregnancy, combined with her admitted use of the drug in the past and her failure to consistently test or enroll in a drug abuse program, justified the juvenile court's exercise of dependency jurisdiction over her children. ${ }^{251}$

It remains unclear whether the court declined to follow the Drake $M$. model - itself beholden to the model delineated in Jennifer A.- because those courts had relied on an earlier DSM edition - thus occasioning questions about which edition to invoke at any point in time - or whether the court simply preferred its own assessment of the parents' capacity to provide adequate care for their children to conclusions dependent on broad diagnostic criteria, presumably shaped without particular cases in mind. In any event, even as the Christopher $R$. court limited application of the Drake $M$. formulation, it engaged in a careful consideration of the criteria for identifying substance abuse delineated in DSM$5{ }^{252}$ The court recognized the Drake M. model as "useful and workable," but not

or exacerbated by cannabis.

10. Tolerance, as defined by either of the following:

a. A need for markedly increased amount of cannabis to achieve intoxication or desired effect.

b. Markedly diminished effect with continued use of the same amount of cannabis.

11. Withdrawal, as manifested by either of the following:

a. The characteristic withdrawal syndrome for cannabis ....

b. Cannabis (or a closely related substance) is taken to relieve or avoid withdrawal symptoms.

DSM-5, supra note 13, at 509-10. DSM-5 provides that mild use involves the "presence of 2-3 symptoms;" moderate use involves the "presence of 4-5 symptoms;" and severe use includes the "presence of 6 or more symptoms." Id. at 510.

250. In re Christopher R., 171 Cal. Rptr. 3d at. 21.

251. Id. (noting in light of the children's "tender age," Crystal's use of cocaine constituted prima facie evidence that she was not able adequately to care for her children).

252. More disturbing, the court's analysis of the facts found by the lower court and its discussion of the decision in Drake M. suggested a disconcerting possibility - that in these case, judicial dependence or not on the DSM was as likely to follow as to shape a court's conclusions. In In re Christopher $R$., the appellate court viewed the mother's having missed a drug test as significant evidence that she would not likely be able to provide adequately for her children. $I d$. at 20 (noting as well that Crystal, the mother, had not enrolled in a substance abuse program nor in 
as a "comprehensive, exclusive definition mandated by either the Legislature or the Supreme Court." 253

4. Cases that Followed.-Drake M. and Christopher R. provided different models regarding judicial reliance - or not - on DSM diagnostic categories with regard to a parent's diagnosis of substance abuse. After Christopher R., some state appellate courts continued to rely on the Drake $M$. formation. Others did not. The first case examined in this subsection compromised between the model in Drake $M$. and that in Christopher $R$. In this case (In re Alezxander C.) . $^{254}$ the court referred to diagnostic criteria included in both DSM-IV-TR and in DSM-5. ${ }^{255}$ That approach supported the trial court's decision against the parents but did not, without more, provide adequate support for affirming that decision. The second case considered in this subsection more clearly followed Christopher R.'s rejection — or, more accurately - its modification — of the Drake M. model. ${ }^{256}$

The appellate court in Alexzander $C$. affirmed a trial court decision that Richard C., father of two minor children, abused methamphetamine to the detriment of the children. ${ }^{257}$ Richard admitted using drugs ${ }^{258}$ but argued that that use did not constitute drug abuse and did not pose a risk of harm to his children. ${ }^{259}$ The appellate court affirmed the lower court ruling that the father was a substance abuser and that that abuse did pose a risk of serious harm to his two

any other program that had been recommended to her and that her attitude to childcare was "cavalier").

In contrast, in Jennifer A., the case on which Drake M. relied in identifying a model that depended on the DSM's diagnostic categories, the court described Jennifer, the mother, to have missed nine drug tests but to have shown "sufficient compliance with the case plan to avoid termination of parental rights." 12 Cal. Rptr. $3 \mathrm{~d} 572,587$. The court in this case noted that the nine missed drug tests (considered positives) and two actual positives did not provide evidence of substance abuse since Jennifer submitted to eighty-four drug tests in which she tested negative for drug use. $I d$.

In sum, the court that found the parent adequate. Jennifer was judged not to reflect the manual's criteria for a substance abuse diagnosis. In contrast, the court that did not believe the parent (Crystal) to be able adequately to care for her children, rejected the Jennifer A. and Drake $M$. model that depended on the DSM for a functional definition of substance abuse. Perhaps that rejection reflected the court's realization that reliance on DSM-5 criteria would have mitigated concern about Crystal's drug use. That was the case even though the court suggested that Crystal would likely have met DSM-5 criteria for a substance disorder diagnosis had those criteria been definitely applied to her case.

253. In re Christopher R., 171 Cal. Rptr. $3 \mathrm{~d}$ at 21.

254. In re Alexzander C., 226 Cal. Rptr. 3d 515, 523 (Cal. Ct. App. 2017).

255. Id.

256. L.A. Cty. Dep't of Children \& Family Servs. v. V.T. (In re Mariah T.), 2015 Cal. App. Unpub. LEXIS 2905 (Cal. Ct. App. 2015).

257. Id. Richard C. and the children's mother, Alina C., had four children. Only two were still minors when the case began. $I d$. at 517 .

258. Id. at 523 .

259. Id. at 521 . 
children still living at home.

Reflecting the approach in Drake M., the appellate court looked to DSM diagnostic categories. But the court shaped a compromise between the models presented in Drake M. and in Christopher R. First, the court delineated the criteria "demonstrate[ing] substance abuse" in DSM-IV-TR (relied on in Drake M.) It then delineated the eleven criteria delineated in DSM-5 for diagnosing someone with a substance use disorder. ${ }^{260}$ The Alexzander $C$. court concluded that both the DSM-IV and DSM-5 diagnostic criteria for substance abuse supported the trial court's finding that the parents' use of drugs, including methamphetamine, posed a significant risk of harm to the children. ${ }^{261}$ Thus the court relied on both DSM-IV and DSM-5 in affirming the lower court's finding of substance abuse but did not presume to condition conclusions in future cases involving claims of parental substance abuse on compliance with DSM diagnostic categories. In re Mariah $T .,{ }^{262}$ a state appellate court followed the holding in Christopher $R$. In doing that, the court expressly limited the reach of the formulation put forth in Drake M. for defining substance abuse in juvenile dependency cases. ${ }^{263}$ Mariah $T$. resembled Drake $M$. and Christopher $R$. in having been occasioned by a parent's challenge to a lower court's finding that the parent was a substance abuser and, as such, a danger to his "children's physical health and safety and place[d] the children at risk of physical harm, damage, and danger."264

The father in Mariah T. relying on DSM categories, contended that there was no "substantial evidence" to support the lower court's finding that he abused substances. In that regard, he noted that the Department of Children and Family Services "did not present evidence that Father had been diagnosed as having a current substance abuse problem by a medical professional or that he had $\mathrm{a}[\mathrm{n}]$ abuse problem as demonstrated by various behaviors within the past twelve months as defined in DSM-IV-TR."265

The father's approach reflected the approach relied on by the courts in Jennifer A. and Drake M. In both cases, courts had overturned a lower court finding of parental substance abuser on the grounds that the parent's behavior did not conform with the criteria for substance abuse delineated in the DSM. However, the court rejected the father's claim that he could not be labelled a substance abuser because his use did not conform with substance abuse behaviors outlined in the DSM.

The Mariah T. court did not comment on the review of DSM-5 diagnostic criteria in Christopher $R$. even though DSM-5 had been published two years before the decision in Mariah $T^{266}$ The appellate court affirmed the lower court's

260. Id. at 523 .

261. Id.

262. L.A. Cty. Dep't of Children \& Family Servs. v. V.T. (In re Mariah T.), 2015 Cal. App. Unpub. LEXIS 2905 (Cal. Ct. App. 2015).

263. Id. at *10-*13.

264. Id. at *5-*6.

265. Id. at $* 6$.

266. Id. at *12-*13. 
findings and dispositional order, referencing the children's young age as grounds for its decision that the father's substance abuse provided "prima facie evidence" of his presenting "a substantial risk of harm" to his children. ${ }^{267}$ In the view of the Mariah T. court, there was no need to support that conclusion through reference to DMS-5 diagnostic categories.

In sum, both courts that premised their conclusions on DSM diagnostic categories and those that did not noted DSM categories and their implications. In general, that process is likely to encourage judges more carefully to review the evidence that a parent is or is not a substance abuser. In that, it promises to contain judicial extravagances, in either direction.

\section{Surrogate Parenting and Disagreements about DSM Diagnoses Among Expert Witnesses}

Experts testifying in a New Jersey case involving a dispute between a surrogate mother and the couple with whom she had entered into a surrogacy contract (the intending parents) presented conflicting interpretations of DSM diagnostic categories. ${ }^{268}$ Expert testimony focused on the surrogate mother's capacity to serve the child and, correlatively, on the child's best interests. The case - in the Matter of Baby $M^{269}$ — arose after the surrogate, Mary Beth Whitehead, declined to comply with the terms of a contract entered into by Whitehead, William Stern, the intending father, and Whitehead's husband, Richard. ${ }^{270}$ The surrogacy contract had provided that should Whitehead become pregnant and give birth to a child conceived through assisted insemination with William Stern's sperm, she would cooperate in effecting the termination of her maternal rights so that Elizabeth Stern, the intending mother and William Stern's wife, could become the child's legal, adopting mother. ${ }^{271}$ In exchange, Stern agreed to pay Whitehead $\$ 10,000$ upon the birth of the child. ${ }^{272}$

Mary Beth Whitehead gave birth to a girl in March 1986 and soon realized that she was unable to give the child to the Sterns. ${ }^{273}$ Without informing the Sterns, she travelled with her husband, Richard, and the baby to Florida. ${ }^{274}$ Several months later, the Sterns located Whitehead and the child in Florida and commenced a proceeding to require Whitehead to return to New Jersey and

267. Id. at *14 (relying on Drake M., 149 Cal. Rptr. at 886 and Rocco M., 2 Cal. Rptr. 2 d at 435).

268. In re Baby M., 537 A.2d 1227 (N.J. 1988), rev'g In re Baby M., 525 A.2d 1128 (N.J. 1987).

269. In re Baby M., 537 A.2d 1227 (N.J. 1988)

270. Id. at 1235 .

271. Id.

272. Id.

273. Id. at 1236. Initially, Whitehead surrendered the baby to the Stern. Id. She became disconsolate. The Stern, concerned that Whitehead would kill herself, agreed to let her have the baby for a short period. Id. at 1237.

274. Id. 
surrender the child to them. ${ }^{275}$ The Sterns sought legal parentage of the child. ${ }^{276}$ The trial court deemed the best interests of the baby to have been its primary consideration in identifying the child's legal parents. ${ }^{277}$ On the basis of its bestinterest determination, the trial court reached a conclusion rarely reached in custody cases: it terminated Mary Beth Whitehead's parental rights and provided for Elizabeth Stern - the intending, but not the biological, mother - to adopt the child.

The trial court heard testimony from thirty-eight witnesses. Eleven offered testimony about the child's best interests. ${ }^{278}$ Most of those eleven experts depended upon psychiatric knowledge, though not necessarily knowledge contained in the DSM. ${ }^{279}$ Two of them invoked the DSM, but to different ends. ${ }^{280}$

275. $I d$.

276. Id.

277. In re Baby M., 525 A.2d at 1132. Judge Sorkow, presiding in the trial court, wrote: "The primary issue to be determined by this litigation is what are the best interests of a child until now called 'Baby M.'”

278. Id.

279. Id. Yet, the court essentially dismissed the testimony of several of these mental health experts. Id. The court was unwilling to place weight on testimony of one expert, P. Silverman, because of her "stated bias against men" and because she had queried whether a male professional was capable of evaluating a female client. Id. Further, the court noted that Dr. Vetter largely testified about Mary Beth Whitehead's capacity to exercise informed consent. The court deemed that concern to have had virtually no relevance to the case. Id. at 1149. Dr. Koplewicz's testimony was criticized by the court because he had "no knowledge of the fundamental criteria that must be established before a court in New Jersey may order joint custody." Id.

280. In reaching its best-interest determination, the trial court relied heavily on the testimony of Dr. Lee Salk, an expert witness for the Sterns. Id. at 1151. Dr. Salk testified on the child's best interests. In that capacity, he offered nine factors that he posited as relevant to a best interest determination. Id. These factors included the child's having been wanted or not; the "emotional stability" of the people in the home environment; the stability and consistency of the family; the ability of the adults to understand and respond to the child's needs, both emotional and physical, the family's position about education and learning; the adults' ability to respond with rationality, especially in difficult situations; the adults' capacity to encourage health and nutrition and to teach the child to avoid substance abuse; the adults' ability to help the child deal with the problems that life presents and to become a "productive member of society." Id. The court took that list very seriously in deciding that the child's best interests lay with the Sterns, not with Whitehead. The court further reported on Dr. Salk's assessment of the Sterns in light of each of the factors he enumerated. Id.

One of the few components of the trial court decision that the state's highest court approved on appeal was the lower court's examination and interpretation of the testimony about the child's best interests. The state's highest court found the trial court's analysis of Dr. Salk's testimony to have been "perceptive." In re Baby M., 537 A.2d 1227, 1238 (1988). For the New Jersey Supreme Court, however, the best interest determination spoke only to the issue of custody and not to that of parentage. Id. After determining that William Stern and Mary Beth Whitehead were the child's legal parents, the appellate court granted custody to Stern and, thus in effect, to his wife, Elizabeth 
One of the two diagnosed Mary Beth Whitehead, the surrogate, with a DSM mental disorder. Dr. M. Schecter, a psychiatrist who testified on behalf of the child's court-appointed guardian ad litem, ${ }^{281}$ concluded on the basis of DSM diagnostic criteria that Mary Beth Whitehead could be diagnosed with mixed personality disorder. ${ }^{282}$

The trial court judge respected the DSM as an authoritative text. He referred to DSM-III (the most recent DSM edition at the time) as "the standard guide of the mental health field used to define mental disorders." 283 Yet, the court did not accept Dr. Schecter's application to Whitehead of a DSM-III diagnosis, largely because Dr. Klein, another of the experts who testified in the case, presented a contrary set of conclusions about the applicability of the DSM diagnosis to Whitehead. ${ }^{284}$ Dr. Klein, a psychiatrist who testified for the Whiteheads, had served on the committee that authored the part of DSM-III on which Dr. Schecter relied. Dr. Klein opined that the symptoms to which Dr. Schecter pointed were not of "sufficiently long duration" to justify diagnosing her with mixed personality disorder. Rather, explained Dr. Klein, the symptoms reflected Whitehead's response to the "present life crisis." 285 Thus, the court dismissed the conclusion of one expert (Dr. Schecter), who relied on DSM-III because another expert (Dr. Klein, who helped author relevant parts of DSM-III) disputed the validity of Schecter's interpretation and diagnosis. ${ }^{286}$

After reviewing the experts' testimony, Judge Sorkow, writing for the trial court, explained that even as the court believed that the experts who testified "deserve respect," ${ }^{287}$ the judge - in this case, the trier of fact - was ultimately

Stern. Id. If William had died or if William and Elizabeth had separated, however, the law would have provided Elizabeth with very little support had she attempted to sustain her relationship with the child. $I d$.

281. 525 A.2d at 1150.

282. Id.

283. Id.

284. Id.

285. Id.

286. The court relied on Dr. Klein's expertise in dismissing Dr. Schecter's diagnosis of Whitehead with a DSM mental disorder. Id. However, the court decided not to place weight on Dr. Klein's own conclusions about Mary Beth's mental health status. Id. 1150-51. Klein administered a test that was "in a developmental state and not accepted by the mental health profession." Id. at 1151 .

Judge Sorkow concluded that the court would not rely on Dr. Klein's findings and would "give minimal weight to [his] conclusions." Id. Similarly, Judge Sorkow downplayed the testimony of another expert who testified for and who 'favored' the Whiteheads - Dr. Sokoloff, a pediatrician. Id. This witness, the court explained, testified on cross-examination that, although he'd opined on the best interests of children raised by birth mothers, by stepparents, by adopting parents and by foster parents, he admitted to having had no special training in early childhood development. Id. For this reason, the court concluded, Dr. Sokoloff had "neutralized himself." Id.

287. Id. at 1156 . 
responsible for analyzing that testimony. "Experts," asserted Judge Sorkow, "are to aid and assist the trier of fact, not to dominate or control him in the decision of the disputed question." 288

Thus, the New Jersey trial court in Baby M. took a position resembling that of some of the California appellate courts that acknowledged, but limited, the model proposed in Drake M. For instance, in In re Alexzander $C .{ }^{289}$ the appellate court reviewed DSM diagnostic categories related to substance use disorder, finding that guidance useful. However, as in Baby M., the court did not treat the DSM categories as determinative. ${ }^{290}$

\section{ASSESSING THE LAW'S RELIANCE ON DSM DIAGNOSTIC CATEGORIES IN LITIGATION INVOLVING PERSONAL STATUS}

The two preceding Parts of this Article show the DSM to have served different functions for both litigants and courts in cases involving first, the rights of transgender populations and second, in cases in which parents faced the possible termination of parental rights. In both sorts of situations, the DSM has provided useful guidelines for courts even though shifts in diagnostic categories between DSM editions have sometimes raised concern for courts as have differences of opinion among psychiatrists about how best to interpret DSM diagnostic categories in the context of particular legal cases.

Psychiatrists, scholars, and judges have criticized judicial reliance on the DSM in general and, specifically, they have criticized reliance on the manual in cases involving questions of personal status. ${ }^{291}$ Successive editions of the manual

288. Id. at 1156. Finally, relying largely on Dr. Salk's enumeration of factors relevant to a child's best interests in determining his or her custody, the court found that the child would best be served by paternal custody. Id. It then concluded that it would specifically enforce the agreement among the parties and terminate Whitehead's maternal rights. Id.

Mary Beth Whitehead appealed. In re Baby M., 537 A.2d 1227 (N.J. 1988). The state's highest court overturned the trial court's holding, characterizing the surrogacy contract into which the parties had entered as "illegal and invalid." Id. at 1235. Moreover, the state supreme court described the trial court's holding to have been in conflict with "the law and public policy of this State." Id. at 1234. Yet, Judge Wilentz, writing for the N.J. Supreme Court, relied on the trial court's best-interest analysis in granting full custody to William Stern. Id. at 1238. The court wrote:

On the question of best interests - and we agree, but for different reasons, that custody was the critical issue - the court's analysis of the testimony was perceptive, demonstrating both its understanding of the case and its considerable experience in these matters. We agree substantially with both its analysis and conclusions on the matter of custody. Id.

289. In re Alexzander C., 18 Cal. App. 5 438, 447 (Cal. Ct. App. 2017).

290. Id.

291. Sisti \& Johnson, supra note 12 , at 96 . Courts have invoked the manual more often in criminal cases than in civil cases. Slovenko, supra note 1, at 6-8. 
were not shaped for use by courts of law; ${ }^{292}$ questions have emerged about the legitimacy of the processes through which the manuals are revised. ${ }^{293}$ More broadly, confidence in the APA's manuals has diminished in the last several years, even within the profession. ${ }^{294}$ Further, DSM-IV and DSM-5 openly caution against unthoughtful reliance on the DSM in legal settings. ${ }^{295}$

All of that notwithstanding, reliance on the DSM in the sort of cases examined in this Article - cases questioning personal status - has assisted courts to make decisions about matters that implicate litigants' personal status and that can therein be of great consequence to people's everyday lives. ${ }^{296}$ Indeed, even as the DSM itself cautioned against use of the manuals in court, both DSM-IV and DSM-5 acknowledge that "[w]hen used appropriately" each edition of the DSM can assist lawmakers. ${ }^{297}$ Both editions explain:

By providing a compendium based on a review of the pertinent clinical and research literature, DSM-IV [and DSM-5] may facilitate the legal decision makers' understanding of the relevant characteristics of mental disorders. The literature related to diagnoses also serves as a check on ungrounded speculation about mental disorders and about the functioning of a particular individual. Finally, diagnostic information about longitudinal course may improve decision making when the legal issue concerns an individual's mental functioning at a past or future point in time. ${ }^{298}$

The APA's own assessment seems reasonable. It might better be viewed as multidimensional than as internally conflicting. The DSM can provide invaluable guidance to courts asked to interpret mental health diagnoses. Yet, it is most likely to offer that guidance felicitously and to serve justice if it is understood as open to interpretation and is applied with wisdom and care in legal settings.

\section{A. The DSM Guides Lawmakers: an Illustration}

A Florida case, G.T. v. Department of Children \& Family Services, ${ }^{299}$ illustrates the value of courts' relying on the DSM "as a check on ungrounded speculation about mental disorders and about the functioning of a particular individual." ${ }^{\prime 300}$ This illustration is particularly compelling because the trial court, which reached what appears to be an unfortunate decision, did not rely on DMS

292. See generally Sisti \& Johnson, supra note 12.

293. Id.

294. Id. at 87.

295. Id.

296. See supra Parts III and IV.

297. See Slovenko, supra note 1, at 6 (noting conflicting assessments of use of DSM diagnostic categories by lawmakers).

298. Id.

299. G.T. v. Dep't Children \& Family Serv., 935 So.2d 1245 (Fla. Ct. App. 2006).

300. Slovenko, supra note 1 , at 6 
diagnostic categories. ${ }^{301}$ The appellate court, which did rely on the manual, reversed the trial court's holding. ${ }^{302}$

Florida law governing mental health services for minors ${ }^{303}$ defined a minor with an "emotional disturbance" or a "serious emotional disturbance" as "a person under 18 years of age" who had been diagnosed with a disorder meeting a diagnostic category in the latest edition of the DSM. ${ }^{304}$ In cases involving family status and the custody or parentage of children, such statutory provisions - requiring testimony from an expert who evaluates his or her findings in light of DSM categories - may preclude potentially draconian responses (e.g., institutionalizing a child not needing in-patient care or terminating the parental rights of parents whose children's interests will not thereby be served).

G.T. was an adolescent whose parents' rights had been terminated. The lower court granted the Department of Children and Family Services' request to place G.T. in a residential mental health facility. In making that determination, the lower court did not rely on DSM categories, and it appeared not to consider the boy's full story. The court relied on hearsay evidence - an assessment report authored by a licensed psychologist who did not reference the DSM and did not appear before the court - in concluding that G.T. should be involuntarily placed in a residential mental health facility. ${ }^{305}$ Yet, witnesses for G.T., including his

301. G.T., 935 So. $2 \mathrm{~d}$ at $1248-49$.

302. Id. at $1249-50$ n. 9 \& n. 10 .

303. Fla. StAT. § 394.492(5) \& (6) (2019).

304. $\$ 394.492(5) \&(6)$. The full statutory definition of each term follows:

5) "Child or adolescent who has an emotional disturbance" means a person under 18 years of age who is diagnosed with a mental, emotional, or behavioral disorder of sufficient duration to meet one of the diagnostic categories specified in the most recent edition of the Diagnostic and Statistical Manual of the American Psychiatric Association, but who does not exhibit behaviors that substantially interfere with or limit his or her role or ability to function in the family, school, or community. The emotional disturbance must not be considered to be a temporary response to a stressful situation. The term does not include a child or adolescent who meets the criteria for involuntary placement under [State law].

(6) "Child or adolescent who has a serious emotional disturbance or mental illness" means a person under 18 years of age who:

(a) Is diagnosed as having a mental, emotional, or behavioral disorder that meets one of the diagnostic categories specified in the most recent edition of the Diagnostic and Statistical Manual of Mental Disorders of the American Psychiatric Association; and

(b) Exhibits behaviors that substantially interfere with or limit his or her role or ability to function in the family, school, or community, which behaviors are not considered to be a temporary response to a stressful situation.

The term includes a child or adolescent who meets the criteria for involuntary placement under [State law]. § 394.492(5) \& (6).

305. The appellate court noted that hearsay evidence may sometimes be admissible in cases such as G.T.'s but could not be "deemed competent, substantial evidence sufficient to support a 
high school's guidance counselor and a teacher, testified that G.T. "had no disciplinary problems, no impulse control problems, no problems being disrespectful to teachers, and had made friends with students who were also good student citizens." ${ }^{306}$

Reversing, the appellate court explained that the lower court's decision did not comport with the requirements of the law - that an order to place a minor in a residential mental health facility must be grounded on evidence offered by a psychiatrist or psychologist ${ }^{307}$ and that state law "contemplate[d] expert opinion attesting to a diagnosis that comports with a disorder specified in the Diagnostic and Statistical Manual of Mental Disorders of the American Psychiatric Association. ${ }^{308}$ Before a court could order that a child be institutionalized, it had to have considered expert psychiatric testimony asserting that the minor suffered from "a mental, emotional, or behavioral disorder" that met "one of the diagnostic categories specified in the most recent edition of the Diagnostic and Statistical Manual." 309

The appellate court decision, and the state law on which that decision relied, acknowledged that diagnosing someone with a mental disorder can have profound legal consequences - in G.T.'s case, his involuntary placement in a residential facility. It is thus reasonable to expect that before a trial court concludes that a child is mentally ill, it consider expert testimony and reasonable to expect that an expert's diagnosis of mental illness comport with a DSM "disorder." These requirements offer some protection against judges-generally untrained in diagnosing mental disorders - too readily concluding that the future of a child (or a parent in relation to his or her child) should be sacrificed to an unsupported presumption of mental illness.

Read together, the lower court decision and the appellate court decision in G.T. show the benefits of judges relying on a professional framework within which to assess a presumptive mental disorder. Had the trial court judge in G.T. heeded state law and entertained psychiatric testimony grounded on DSM diagnostic categories, that judge would likely not have ordered that the boy be confined to a mental health facility.

The shortcomings of the DSM for use in legal settings notwithstanding, in cases such as G.T. the framework provided by DSM diagnostic categories, interpreted by experts, can be invaluable in guiding judges' decision making. Moreover, the DSM carries significant professional weight. ${ }^{310}$ Thus, the manual

factual finding." Id. at 1252 .

306. Id. at 1248 .

307. Florida law required that evidence that a child should be placed in residential mental health care because of an emotional (or "serious emotional") disturbance had to be offered by "“a psychiatrist or a psychologist licensed in Florida." Id. at 1249 (citing FLA. STAT. § 39.405(6)(b) (2005).

308. Id. at 1249 (citing Fla. STAT. § 394.492(5) \& (6) (2005)).

309. Id. at 1249-50.

310. Teneille R. Brown, From Bibles to Biomarkers: The Future of the DSM and Forensic Psychiatric Diagnosis, 2015 UtAH L. Rev. 743, 746 ("lawyers and judges often refer to the DSM 
can guide judges in cases involving parent-child relationships (as well, of course, as in other sorts of cases). State laws, such as Florida's, that predicate courts' conclusions about a party's mental status on professional guidelines aim to reduce, even if they do not always obliterate, impressionistic decision-making that may do a disservice to litigants.

\section{B. Benefits of Reliance on the DSM in Personal Status Cases: a Summary}

DSM diagnostic categories can guide judges, offering them a tool for responding to claims of mental illness in personal status cases. Yet, that tool must be handled with caution. This Section delineates some of the reasons that caution in judicial reliance of DSM categories is in order for that reliance to provide the greatest benefit.

Even as reliance on the DSM can structure legal decision making in cases that necessitate an understanding of mental illness, that reliance does not transform non- professionals, including judges, into psychiatrists. The mediation of experts is essential in cases such as those examined in this Article. Psychiatric experts are generally aided, in turn, and can thus better assist courts more forcefully, through references to the professional manuals such as the DSM.

Still, however, judicial caution should be exercised when relying on the DSM. This call for caution, which reflects the DSM's own disclaimers about the usefulness of DSM diagnostic categories in legal settings, ${ }^{311}$ is justified by a set of potential stumbling blocks that may face court's relying on the DSM to assess litigants' mental health. The task of interpreting shifts between DSM editions - a task that may befuddle even professionals ${ }^{312}$ - has confused judges. ${ }^{313}$ Judicial reliance on one DSM edition instead of another can carry significant consequences for litigants. Furthermore, caution is in order insofar as successive editions of the DSM not only reflect advances in psychiatry; they also reflect socio-cultural shifts. ${ }^{314}$ And sometimes they reflect financial motives that do not serve patients. ${ }^{315}$

The most recent DSM edition at any point in time has often been considered the most reliable, ${ }^{316}$ but courts have sometimes approved testimony offered by an

as the "psychiatric bible"” (citing Warren Moïse, Shrink Rap, 20 MAR. S.C. LAW. 13, 13 (2009)).

311. See, e.g., DSM-5, supra note 13, at 25; see supra notes and accompanying text.

312. See, e.g., Pickersgill, supra note 49, at 40; Wakefield, supra note 44, at 139.

313. See supra Part II.

314. See Sisti \& Johnson, supra note 12, at 79 (noting "psychiatric nosology . . draw[s] on cultural norms").

315. Id. at 87.

316. See In re Timothy Maurice B., 626 N.Y.S.2d 665 (N.Y. Fam. Ct. 1995). A New York court rejected one expert's testimony about the mental status of a parent because that expert had relied on DSM-III-R even though DSM-IV was available. Id. The court explained:

The court is not prepared to accept an opinion rendered under DSM-III-R when DSM-

IV was the operative professional Manual. This court cannot accept the explanation that the Family Court Mental Service allowed its doctors to render opinions based on an 
expert relying on an older edition of the manual. For instance, a New Jersey court accepted the explanation of an expert who had relied on DSM-IV diagnostic categories even though DSM-5 had been published with a somewhat different presentation of the categories at issue. ${ }^{317}$ The court explained that "there ha[d] been significant professional controversy over the DSM-V [sic]"318 and, thus, it was comfortable relying on an earlier edition of the manual.

The role of social and cultural influences in shaping successive DSM editions has occasioned concern. The extent to which the APA should consider the preferences of constituents, ${ }^{319}$ especially advocates and patients, has been a matter of contention. ${ }^{320}$ Two commentators have suggested that patients and patient advocates "should be able to hold the APA accountable for decisions that they think undermine rather than advance their interests." ${ }^{" 321}$ That sentiment opens a path along which constituents can play a role in shaping DSM revisions in light of their perceived needs and preferences.

Ties between industry (especially pharmaceutical companies) and psychiatrists have occasioned serious concern about the effects of authors' conflicts-of-interest on the shaping of the DSM. ${ }^{322}$ Correlatively, changes in the DSM may be motivated by an interest in expanding payor coverage. The decision of DSM-5 authors to eliminate the DSM-IV distinction between Axis-I (clinical) disorders and Axis-II (personality) disorders may, for instance, have been motivated by an interest in increasing the likelihood that payors would pay providers for treatment related to particular psychiatric treatments. ${ }^{323}$ Further, the proliferation of diagnoses is likely to increase coverage for the treatment of mental health disorders.

These factors - shifts in diagnostic categories between DSM editions, the role of social and cultural factors in shaping new diagnostic categories, and conflictsof-interest resulting from ties between DSM authors and industry and,

outdated Manual and that they had more than six months . . . before being required to use DSM-IV.

Id. at 669-70 (noting that "a near-final draft of DSM-IV had been in circulation for a year so that members of the profession could study and critique it before final release in May 1994").

317. N.J. Div. Child Protection \& Permanency v. J.L.C., No. A-3727-17T2, 2019 WL 2060279 (N.J. Super. Ct. App. Div. 2019) (holding against parents who appealed a decision to terminate their parental rights to their son).

318. Id. at $* 2$.

319. Sisti \& Johnson, supra note 12, at 81. (noting four constituencies affected by revisions in the DSM: "allied behavioral health and medical professionals;" "mental health researchers;" "current or future patients;" and payors.)

320. Id. at 84 .

321. Id. at 82 .

322. Id. at 87 (noting "[t]rust in psychiatry in general and the APA specifically has waned significantly since the release of DSM-IV, in part due to worries about academic-industry relationships").

323. Id. at 95 (suggesting that elimination of Axis I and Axis II distinction may reflect interest in increasing coverage options for psychiatric care). 
correlatively, an interest in increasing payors' readiness to cover treatment for mental disorders - justify caution in lawmakers' reliance on the DSM. That said, reliance on the manuals can be of significant assistance to lawmakers seeking to discern the scope, relevance and implications of psychiatric diagnoses.

In short, the DSM, used with appropriate attention to the issues at stake and the manual's purpose, provides a framework for decision making that limits unsupported, impressionistic responses among judges and other lawmakers. This establishes a significant safeguard to people diagnosed with mental illnesses involved in litigation that can seriously affect their freedom. ${ }^{324}$ Thus, courts should continue to seek guidance from the DSM while recognizing that its diagnostic categories have often been shaped in light of social, cultural, and economic processes and preferences and must, therefore, be appropriated thoughtfully.

\section{CONCLUSION}

The DSM has been called psychiatry's "Bible." 325 However, in courtrooms the DSM offers a valuable framework and set of guideposts, but it should not be viewed as reflecting objective or eternal truth. Successive editions of the DSM have proven themselves useful to courts considering litigants' mental health. Yet, it is incumbent upon judges who rely on DSM diagnostic categories to be informed about their limitations. The implications of the categories can be murky. And the stakes are high: the consequences of diagnosis with a mental disorder for litigants and those connected to them can hold momentous consequences.

Litigation initiated by transgender populations seeking fairness has been furthered by the appearance of DSM-5. ${ }^{326}$ That edition's revisions, responsive to the preferences of transgender people and shaped in tune with shifts in social and cultural processes, identified "gender dysphoria," but not gender identity, as a "disorder." That change mitigated the stigmatization that followed earlier DSM editions' characterization of transgender status while, at the same time, providing a diagnosis to those seeking coverage for a medical transition. ${ }^{327}$ The use of DSM diagnostic categories in cases involving the termination of parental rights is older and has brought diverse consequences for parents diagnosed with mental disorders and for their children in cases challenging parental rights initiated by

324. Sisti \& Johnson, supra note 12, at 96 (providing examples of reliance on DSM in cases involving persons diagnosed with paraphilia disorders and in cases involving parents diagnosed with mental disorders at risk for losing parental rights).

325. Cynthia M.A. Geppert, Is the DSM the Bible of Psychiatry?, Psychiatric Times (Dec. 1, 2006), https://www.psychiatrictimes.com/bipolar-disorder/dsm-bible-psychiatry/page/0/1 [https://perma.cc/82YU-HA6A] (noting that the "popular press, and even . . scholarly papers" refer to the DSM as a "Bible").

326. See supra notes 71-80 and accompanying text (describing treatment of transgender status in DSM-5).

327. See supra Part III. 
the state ${ }^{328}$ and by private parties. ${ }^{329}$ The authority of courts to identify parents with a mental disorder creates a profound responsibility. Reliance by judges on DSM categories channels idiosyncratic judicial interpretations of a parent's mental state and mitigates bias regarding parents diagnosed with a mental illness.

That the guidance of the DSM is imperfect does not gainsay the manual's usefulness in courtrooms. DSM diagnostic categories and the experts who interpret them offer a powerful framework to judges handling cases in which a litigant's mental health status has been questioned. At the same time, that framework is most likely to protect litigants and society's interests if judges are aware of the DSM's scope and its limitations. The manual has the power to stigmatize or to protect and support people diagnosed with mental disorders. The DSM has been celebrated as a compendium of psychiatric diagnoses, comparable within psychiatry to a sacred text among theologians. ${ }^{330}$ Yet, its essential perspective and its framework have been transformed over time. ${ }^{331}$ Moreover, changes in successive editions reflect the fruits of psychiatric research, and they reflect shifting socio-cultural tides or, more troubling, financial conflicts of interest. Finally, judges relying on DSM diagnostic categories must understand that those categories and the psychiatric testimony that interprets them may have to be "translated" before they harmonize with legal principles. ${ }^{332}$ Psychiatrists, who may "lack knowledge of the law," should not "replace . . . judges" or be accepted as "impartial factfinders." 333 In response to that possibility, it becomes incumbent on judges seeking guidance from the DSM actively to assess psychiatric testimony through the lens of the law.

328. See supra Part IV.

329. See, e.g., In re Baby M., 525 A.2d 2544 (N.J. Ct. App. 1987), rev'd 537 A.2d 1227 (N.J. 1988); see supra Section IV(D).

330. Geppert, supra note 325.

331. Slovenko, supra note 1, at 6.

332. Brooks, supra note 9, at 283.

333. Id. 